\title{
Comparison of exposure to traffic-related pollutants on different commuting routes to a primary school in Jinan, China
}

\author{
Farun $\mathrm{An}^{1} \cdot$ Jiying $\mathrm{Liu}^{1,2}\left(\mathrm{D} \cdot\right.$ Wanpeng $\mathrm{Lu}^{1} \cdot$ Daranee Jareemit ${ }^{3}$
}

Received: 9 September 2021 / Accepted: 23 December 2021 / Published online: 29 January 2022

(c) The Author(s), under exclusive licence to Springer-Verlag GmbH Germany, part of Springer Nature 2021

\begin{abstract}
Traffic-related pollutants seriously affect human health, and the commute time to and from school is the time when students are exposed greatest to traffic pollution sources. Field measurements were conducted with hand-held instruments while walking along two selected commuting routes in winter and spring. The measured data were then compared with background monitoring data, and the respiratory deposition dose (RDD) was calculated to assess the exposure risk. Particulate matter intake from 2018 to 2020 was calculated. In winter, the average concentrations of $\mathrm{PM}_{2.5}$ and $\mathrm{PM}_{10}$ were higher in the afternoon than in the morning. The highest concentration was 2.94 times greater than the background value. The lowconcentration distribution area of the low-traffic route that is off the main road (route B) was more significant than that of the high-traffic route that is near the main road (route A). Moreover, the RDD of route B was consistently lower than that of route $\mathrm{A}$, while the average annual amount of $\mathrm{PM}_{2.5}$ inhalation on route $\mathrm{B}$ in 3 years was $16.3 \%$ lower than that on route A. Overall, route B is more suitable than route A for students to commute on foot. Based on the findings, a walking route located within a community is a good choice.
\end{abstract}

Keywords Traffic $\cdot$ Particulate matter concentration $\cdot$ Primary school $\cdot$ Commuting route $\cdot$ Spatial variation $\cdot$ Respiratory deposition dose

\section{Introduction}

With the continuous development of the economy and society, car ownership gradually increases (Dillman et al. 2021), which is accompanied by increases in the concentrations of traffic-related pollutants (Zheng et al. 2021). Exposure to traffic-related pollution affects the human respiratory system (Bai et al. 2018; Brugha and Grigg 2014) and the cognitive and developmental nervous system (Basagana et al. 2016; Sunyer et al. 2017) and may cause damage to other organs

Responsible Editor: Lotfi Aleya

Jiying Liu

jx183@sdjzu.edu.cn

1 School of Thermal Engineering, Shandong Jianzhu University, \#1000 Fengming Road, Jinan 250101, China

2 Shandong GRAD Group, Built Environment Design and Research Institute, Dezhou 253000, China

3 Faculty of Architecture and Planning, Thammasat University (Rangsit Campus), Khlong Nueng 12121, Pathum Thani, Thailand and tissues of the human body (Bhaskaran et al. 2011; Pang et al. 2021; 2016; van Berlo et al. 2010). More severe cases of pollution exposure lead to increased mortality (Cui et al. 2020; Tang et al. 2020; Walker et al. 2019). Primary school students are at a developmental stage, and their body systems and organs are immature. Thus, if they are exposed to high levels of traffic pollution, they may suffer more damage than ordinary adults. The recurrence of respiratory diseases such as respiratory infection, pneumonia, asthma, tracheitis, and bronchitis within 1 year among children in severely polluted primary schools is higher than that in lightly polluted primary schools (Chen et al. 2019; Kim et al. 2013). The risk of asthma increases as the traffic-related pollution exposure increases near schools, with a hazard ratio (HR) of 1.45 and $95 \%$ confidence interval ranging from 1.06 to 1.98. In models with nitrogen dioxide and simulated traffic exposure, asthma was independently associated with traffic-related pollution in schools, and the effect of nitrogen dioxide was attenuated $(\mathrm{HR}=1.37 ; 95 \% \mathrm{CI}=0.69-2.71)$ (McConnell et al. 2010). Moreover, in addition to health problems, exposure to high concentrations of traffic pollution can result in a decline in students' performance (Pastor 
et al. 2004; Rosofsky et al. 2014) and reduced attendance (Mohai et al. 2011). Therefore, attention should be paid to students' exposure to traffic pollution.

Many studies have investigated the concentrations of these pollutants both in and around schools (Brown et al. 2021; Kumar et al. 2020b; Sunyer et al. 2017; Wadlow et al. 2019), and many meaningful conclusions and mitigation measures have been determined (Dirks et al. 2016; He et al. 2020; Kumar et al. 2020a). While the research on traffic pollutants around schools is currently increasing, the research scope is relatively large, and most studies focus on the overall impact of traffic.

Vehicle exhaust and road dust are the main causes of the increases in concentrations of particulate matter (Harrison et al. 2021). Traffic-related pollutants have limited distribution distances due to obstruction from buildings and trees, as well as interference from airflow (Ozdemir 2019). The commuting period is the time during which students are most directly exposed to automobile exhaust. Compared with other daily activities, students are closer to vehicles, directly exposed to traffic-related pollutants, and have a higher exposure time ratio, especially in traffic hot spots (Buonanno et al. 2013; Dons et al. 2011; Rivas et al. 2016). Moreover, school times coincide with the morning rush hour, and signalized traffic intersections will have particularly high concentrations of particulate matter due to delays and stops of road vehicles, increasing the risk of exposure (Goel and Kumar 2015). Different modes of commuting and different commuting routes can cause people to inhale different concentrations of pollutants (Ahmed et al. 2020; Karageorgou et al. 2021; Qiu et al. 2017).

The state of urban pollution is monitored by uniformly arranged air quality monitoring stations, the location and monitoring range of which are fixed and limited. Generally, monitoring stations are located far from school areas, so they cannot represent the pollutant concentration around schools and on commuter routes. It is especially difficult to promptly reflect the increase of pollution levels in local areas caused by urban traffic peaks or commuter transport peaks (Song et al. 2020; Tischer et al. 2019). This makes the assessment of students' exposure too optimistic, which can pose a greater health risk to students.

This study compares measured data with background data to analyze the gap between them and ultimately provide support for the establishment of roadside traffic monitoring points. In this study, two different commuting routes were selected, one of which (route B) is away from the main road and the other of which (route A) is near the main road, to measure the concentrations of particulate matter during the commuting period. The respiratory deposition dose (RDD) of particulate matter was calculated, and the exposure of students during commuting was assessed. Furthermore, according to the ratio of the measured data to the background data, the difference in the amount of particulate matter inhaled on fixed routes in 3 years was analyzed to prove the importance, and identify the factors, of route selection. The framework of this paper is shown in Fig. 1.

\section{Literature review}

Many studies have explored the pollution status of different routes or at different times. For instance, Garcia-Algar et al. (2014) tested the concentration of ultrafine particles (UFPs) on three different streets and distinguished the pollution at both infant height and adult height; the results showed that babies in strollers were exposed to higher levels of pollution than walking adults. Kumar et al. (2017) measured the pollutant concentration along a given route during commuting time, and it was found that the particulate matter concentration (PMC) and particulate matter number (PNC) to which infants were exposed were significantly increased during the peak period, especially at intersections and bus stops. Elford and Adams (2019) developed a pollutant dose model for commuting that combines the impacts of the commuting mode and topographic forced ventilation rate to predict pollutant concentrations on different routes and proposed the concept of low-dose routes. Mölter and Lindley (2015) analyzed the costs and benefits of fast routes and primary school walking routes with lower pollution exposure via a geographic information system (GIS); the results demonstrated that the relative degree of the reduction of pollution exposure is greater than the relative degree of the increase of the path length. Li et al. (2017) evaluated the pollution exposure on different routes and by different modes of transportation via real-time measurements; the mobile personal monitoring results indicate that motorcyclists are exposed to high levels of pollutants for short periods of time during commuting. The results of these studies effectively provide recommendations for the selection of commuting routes with less pollution to improve the health of citizens, and the specific research contents are summarized in Table 1.

Via the preceding literature review, it is evident that previous studies have involved the comparison of the pollutant concentrations of different routes and different modes of commuting, but there have been relatively few studies on student

groups. There are few practical methods for the measurement of pollutant concentrations on different student commuting routes, and most methods are model predictions. In many previous studies, the measurement time was chosen as the traffic rush hour, but this does not completely coincide with the school commuting time; the afternoon commute of primary school students is sometimes earlier than the evening rush hour. Therefore, based on these shortcomings, the present research focuses on students who are more 
Fig. 1 The framework of this paper

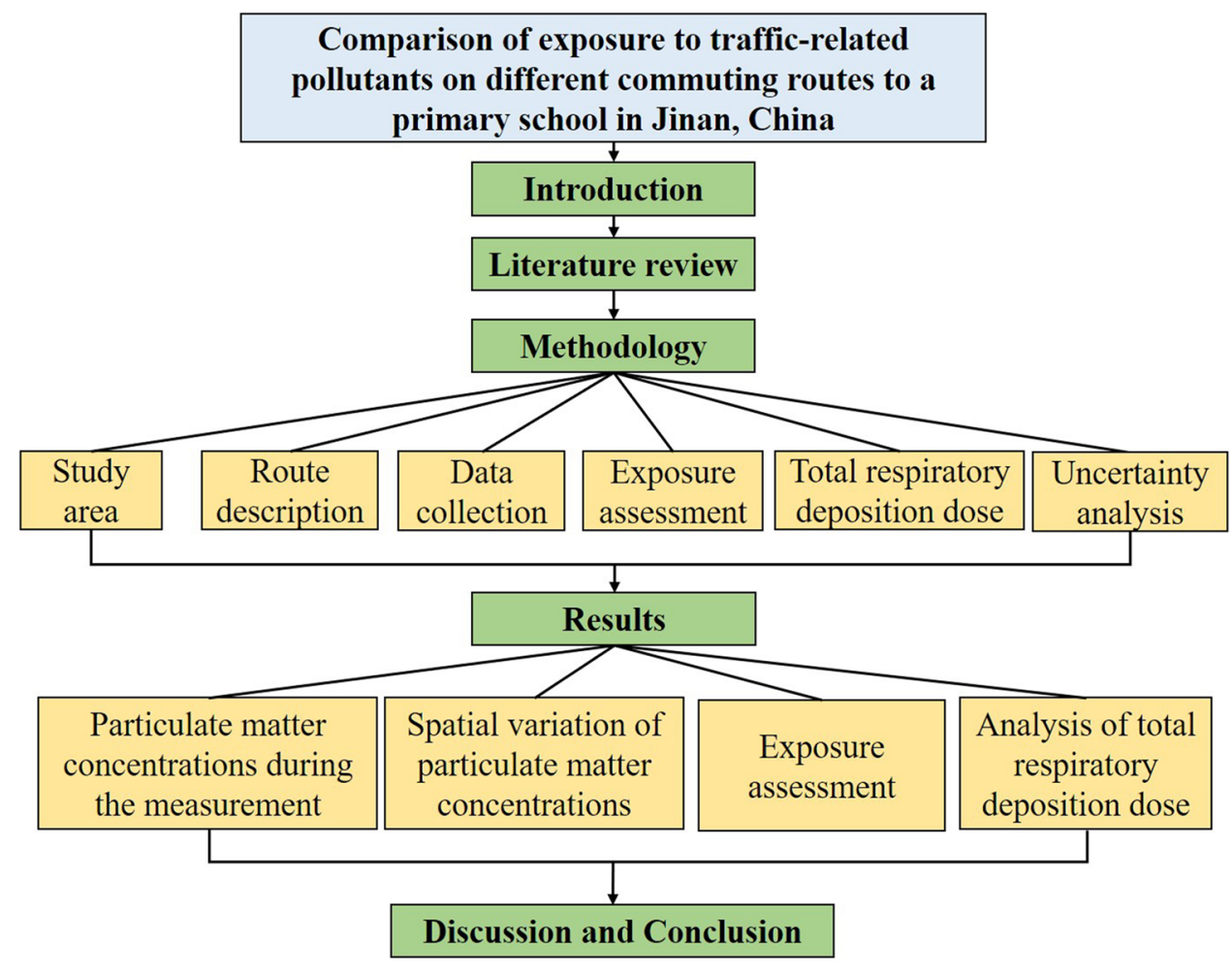

vulnerable to traffic pollution. In addition, field measurements were carried out strictly according to the commuting time of students, and an exposure risk assessment was carried out to effectively provide suggestions for students' choice of commuting routes.

\section{Methodology}

\section{Study area}

The study was conducted in the No. 2 middle school attached to the Shandong Normal University (SDNU), Licheng District, Jinan, Shandong Province, China. Jinan is located in the central part of Shandong Province with a geographical location between $36^{\circ} 02^{\prime}-37^{\circ} 54^{\prime} \mathrm{N}$ and $116^{\circ} 21^{\prime}-117^{\circ} 93^{\prime} \mathrm{E}$, as shown in Fig. 2a. It is located in the warm temperate continental monsoon climate zone and has four distinct seasons. The dominant wind direction is east in winter and changeable in spring. Jinan is also an important transportation hub; by the end of 2019, the number of motor vehicles in Jinan had reached 2.8533 million. During the study, particulate matter data were collected from the air quality monitoring site of Shandong Jianzhu University, which is the closest monitoring site to the study area. The linear distance.

of the monitoring site from the measurement origin is $1500 \mathrm{~m}$, and the relative position is shown in Fig. 2 b.

\section{Route description}

As presented in Fig. 3, the origin of the measurement was the Jianda garden community, and the destination was the school gate. To understand the exposure to traffic-related pollutants on different routes, two representative routes, namely, route $\mathrm{A}$ and route $\mathrm{B}$, were selected for the test. Route $\mathrm{A}$ is the route on the left side of Fig. 3a; it is approximately 760-m long and passes the main road and crossroads, which have heavy traffic. Route $B$ is the route on the right side of Fig. 3a; it is approximately 742-m long and passes a road and park path in the community. Routes $\mathrm{A}$ and $\mathrm{B}$ have similar numbers of commuting students, and the students' families live in the community adjacent to the school, so the routes are very short. It should be noted that although the linear distance of route B appears relatively short on the map, route B contains three sets of steps (as shown in Fig. 3c). Thus, the time required to walk along the two routes is similar, as are the students' preferences for routes A and B.

\section{Data collection}

The concentration and exposure risk of traffic-related pollutants are higher in winter, while the concentration of other seasonal pollutants is relatively low. The increased rainy weather in the summer is not conducive to the measurements conducted in the present study. Moreover, while the pollutant concentrations in spring and autumn are similar, 
Table 1 A review of studies that have evaluated traffic-related pollutants on different routes

\begin{tabular}{|c|c|c|c|c|c|c|c|}
\hline Authors & Method & Period & Parameter & Route distance & $\begin{array}{l}\text { Transportation } \\
\text { mode }\end{array}$ & People & City \\
\hline $\begin{array}{l}\text { Garcia-Algar } \\
\text { et al. (2014) }\end{array}$ & Measurement & 17:00-21:00 & $\begin{array}{l}\text { UFPs }(20- \\
1000 \mathrm{~nm})\end{array}$ & $5 \mathrm{~km}$ & Walking & Infants, adults & Barcelona, Spain \\
\hline $\begin{array}{l}\text { Kumar et al. } \\
\text { (2017) }\end{array}$ & Measurement & $\begin{array}{l}08: 00-09: 00 \\
15: 00-16: 00\end{array}$ & $\begin{array}{l}\text { PMC }(0.25- \\
32 \mu \mathrm{m}) ; \mathrm{PNC} \\
(0.2-1 \mu \mathrm{m})\end{array}$ & $2.7 \mathrm{~km}$ & Walking & Infants & Guildford, UK \\
\hline $\begin{array}{l}\text { Elford and } \\
\text { Adams (2019) }\end{array}$ & $\begin{array}{l}\text { Simulation } \\
\quad \text { (simulated } \\
\text { routes and dos- } \\
\text { age models) }\end{array}$ & & UFPs & $<1.6 \mathrm{~km}$ & Walking & Children & Toronto, Canada \\
\hline $\begin{array}{l}\text { Mölter and Lind- } \\
\text { ley (2015) }\end{array}$ & $\begin{array}{l}\text { Simulation (net- } \\
\text { work analysis } \\
\text { and GIS) }\end{array}$ & & $\mathrm{NO}_{2}, \mathrm{PM}_{10}$ & $<1.5 \mathrm{~km}$ & Walking & Children & $\begin{array}{l}\text { Manchester, } \\
\text { England }\end{array}$ \\
\hline Li et al. (2017) & $\begin{array}{l}\text { Simulation (GIS } \\
\text { and inverse } \\
\text { distance } \\
\text { weighting) and } \\
\text { measurement }\end{array}$ & 07:00-09:00 & $\begin{array}{l}\mathrm{PM}_{1}, \mathrm{PM}_{2.5} \\
\mathrm{PM}_{10}\end{array}$ & & $\begin{array}{l}\text { Motorcycle, } \\
\text { bicycle, walk- } \\
\text { ing }\end{array}$ & Commuters & Taipei, China \\
\hline $\begin{array}{l}\text { Ragettli et al. } \\
\text { (2014) }\end{array}$ & $\begin{array}{l}\text { Simulation (air } \\
\text { pollution mod- } \\
\text { els: PROKAS, } \\
\text { ESCAPE, Pol- } \\
\text { luMap) }\end{array}$ & & $\mathrm{NO}_{2}$ & & Bicycle, walking & Commuters & Basel, Switzerland \\
\hline $\begin{array}{l}\text { Miao et al. } \\
\text { (2015) }\end{array}$ & $\begin{array}{l}\text { Cross-sectional } \\
\text { study }\end{array}$ & & $\begin{array}{l}\text { Polycyclic } \\
\text { aromatic hydro- } \\
\text { carbons }\end{array}$ & $\leq 304.8 \mathrm{~m}$ & $\begin{array}{l}\text { Bus, metro/train, } \\
\text { bicycle, foot, } \\
\text { motorcycle, } \\
\text { truck, car }\end{array}$ & Commuters & Montreal, Canada \\
\hline Li et al. (2015) & Measurement & $\begin{array}{l}07: 00-09: 30 \\
14: 00-16: 30\end{array}$ & $\mathrm{BC}, \mathrm{PM}_{2.5}$ & & $\begin{array}{l}\text { Taxi, bus, sub- } \\
\text { way, cycling, } \\
\text { walking }\end{array}$ & Commuters & Shanghai, China \\
\hline $\begin{array}{l}\text { Cole-Hunter } \\
\text { et al. (2012) }\end{array}$ & Measurement & 07:00-08:00 & $\begin{array}{l}\text { PNC, particle } \\
\text { diameter }\end{array}$ & & Bicycle & Cyclists & $\begin{array}{l}\text { Brisbane, Aus- } \\
\text { tralia }\end{array}$ \\
\hline
\end{tabular}

the concentration of coarse particulate matter may sometimes increase in spring due to sand dust ( $\mathrm{Li}$ et al. 2019), which is a factor that requires consideration. Jinan has a typical temperate monsoon climate, with high temperature and rain in summer, cold and dry in winter, and four distinct seasons (Zhu et al. 2018). Jinan is from March to May in spring, from June to August in summer, from September to November in autumn, and from December to February (next year) in winter. Ultimately, measurements in winter were carried out in January 2021, while measurements in spring were carried out in April 2021. The test periods were consistent with students' commuting times, namely, from 06:30 to 08:00, and from 15:30 to 17:00. The duration of each test was $10 \pm 1 \mathrm{~min}$. To facilitate data processing, each test was numbered. The pollutant concentrations along route $\mathrm{A}$ were measured 70 times in 35 rounds, which are respectively numbered as $\mathrm{A} 1-\mathrm{A} 70$. The pollutant concentrations along route $\mathrm{B}$ were measured 68 times in 34 rounds, which are respectively numbered as B1-B68. The correspondence between specific test dates and numbers is reported in Table 2. Background data from the monitoring station were obtained from the China Air Quality Online Monitoring and Analysis Platform (Wang 2013). The background hourly meteorological conditions during the measurement are presented in Fig. 4. In this paper, according to ASHRAE113-2013 standard, draft rate during the test was calculated (ASHRAE 2013), as shown in Fig. 4c. Eightynine percent of the test time, students felt draft sensation, but there was no difference in the dissatisfaction of the two routes, which had no influence on students' choice of routes. Moreover, it should be noted that wind speed affects the distribution of particulate matter (Mei et al. 2018), and the average wind speed in the study area in spring is greater than that in winter.

Two multifunctional air quality detectors (CEM DT-9883 M, China) were used to collect particulate matter concentration data on the levels of both $\mathrm{PM}_{2.5}$ and $\mathrm{PM}_{10}$. The concentrations of particulate matter concerned are the mass concentration of accumulative counts measured in six channels, with a size range ranging from 0.3 to $10 \mu \mathrm{m}$ (Fig. 5a). The instrument works according to the principle of light scattering and uses a pump to draw 


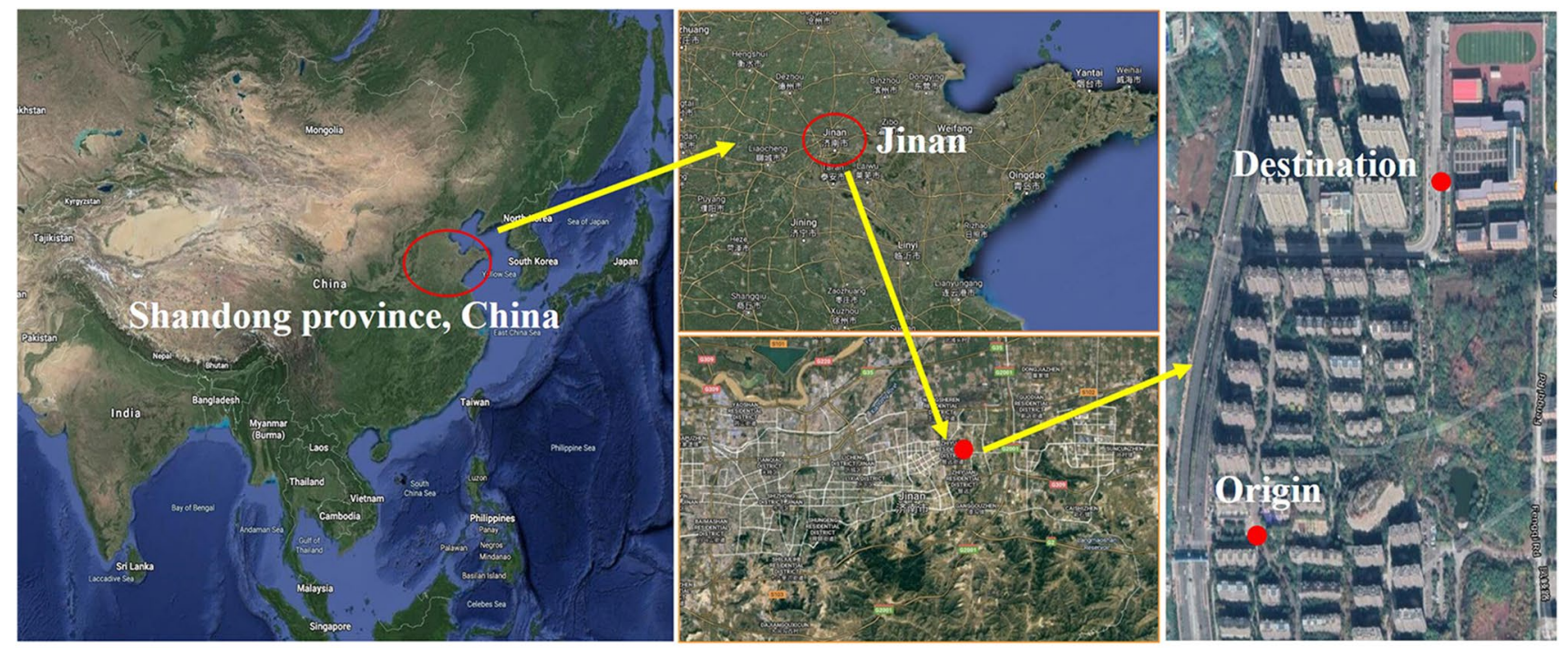

(a)

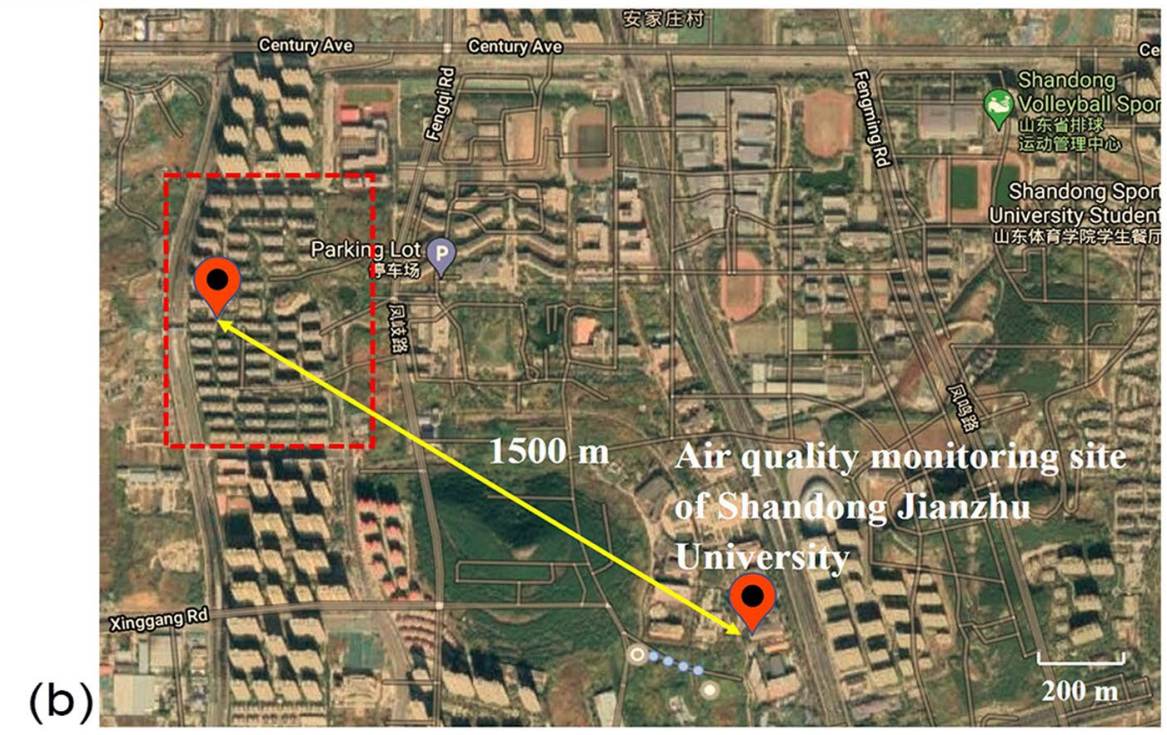

Fig. 2 The geographic location of the test site: a the location of the test site; $\mathbf{b}$ the position of the test area relative to the nearby background monitoring station

air into the measuring chamber. The air in the measuring chamber generates light pulse signals by scattering light beams, which are then converted into pulse signals related to the number of particles (Adeniran et al. 2017; Goyal and Kumar 2013; Onyango et al. 2019; Srimuruganandam and Shiva Nagendra 2010). Finally, each channel converts the quantity signal into mass concentration signal through the conversion equation. The instrument response time is less than $10 \mathrm{~s}$. The sampling flow rate was $2.83 \mathrm{~L} / \mathrm{min}$. The concentrations of $\mathrm{PM}_{2.5}$ and $\mathrm{PM}_{10}$ were measured within the range of $0-2000 \mu \mathrm{g} / \mathrm{m}^{3}$, and the measurement accuracy was $1 \mu \mathrm{g} / \mathrm{m}^{3}$. The test interval was $10 \mathrm{~s}$. The instruments were calibrated by the manufacturer prior to the start of measurement for both seasons. Field calibration was performed by weighing the mass of the polytetrafluoroethylene filter that collected particles during the test and comparing it with the particle mass data generated by the instrument (Adeniran et al. 2017; Kumar and Goel 2016; Pipal et al. 2011). The location of the researchers was recorded once per second using a Global Positioning System (GPS, Zhuolin A8; Fig. 5b). All the instruments were carried by the researchers in backpacks at a height of approximately $1.2 \mathrm{~m}$, which represents the average breathing height of the children. The field measurements were conducted when the students were walking and keeping pace with their walking speed, in order to realistically collect the exposure of particulate matter during the walking commute. Note that the mobile testing method has been extensively used as shown in the Table 1 . 


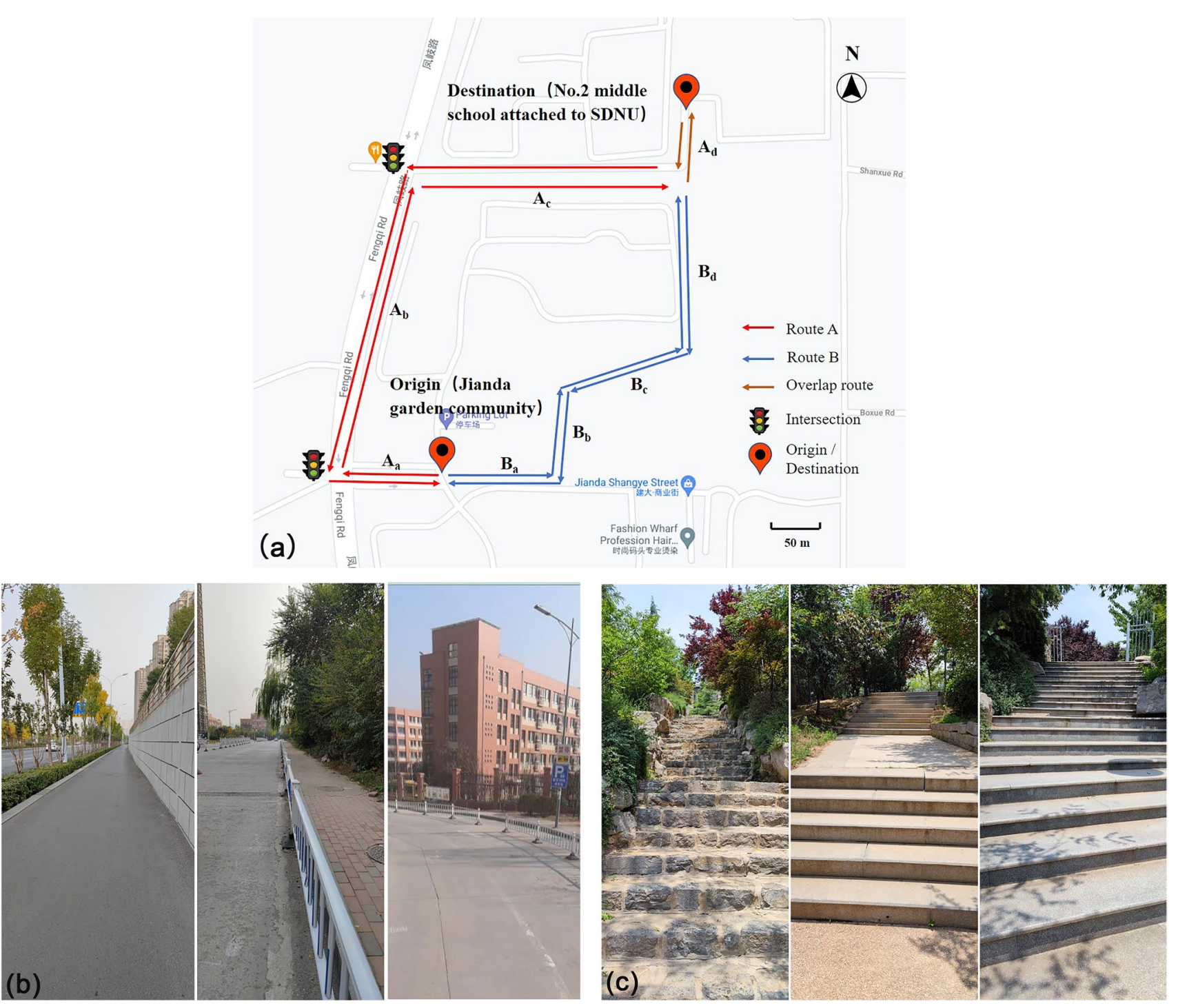

Fig. 3 The characteristics of the test routes: a map; $\mathbf{b}$ steps on route A; $\mathbf{c}$ steps on route B

Table 2 The test dates and test numbers

\begin{tabular}{|c|c|c|c|c|c|}
\hline \multirow[t]{2}{*}{ Season } & \multirow[t]{2}{*}{ Date } & \multicolumn{2}{|l|}{ Morning } & \multicolumn{2}{|l|}{ Afternoon } \\
\hline & & Route A & Route B & Route A & Route B \\
\hline \multirow[t]{2}{*}{ Winter } & 2021 Jan 15 & $\mathrm{~A} 1-\mathrm{A} 6$ & B1-B6 & $\mathrm{A} 7-\mathrm{A} 12$ & B7-B14 \\
\hline & 2021 Jan 20 & A13-A18 & B15-B22 & A19-A24 & - \\
\hline \multirow[t]{8}{*}{ Spring } & 2021 Apr 07 & A25-A30 & B23-B28 & & \\
\hline & 2021 Apr 08 & & & A31-A36 & B29-B34 \\
\hline & 2021 Apr 12 & A $37-A 42$ & B35-B40 & & \\
\hline & 2021 Apr 14 & A43-A46 & B41-B44 & & \\
\hline & 2021 Apr 19 & A47-A52 & B45-B50 & & \\
\hline & 2021 Apr 21 & A53-A58 & B51-B56 & & \\
\hline & 2021 Apr 28 & & & A59-A64 & B57-B62 \\
\hline & 2021 Apr 29 & & & A65-A70 & B63-B68 \\
\hline
\end{tabular}

\section{Exposure assessment}

Exposure was assessed using the RDD based on the International Commission on Radiological Protection (ICRP) model (Hinds 1999). The RDD was estimated according to Eq. (1) and is related to the tidal volume $\left(V_{T}, \mathrm{~cm}^{3}\right)$, breathing frequency ( $B F$, breaths/second), deposition fraction $(D F)$, and $\mathrm{PMC}$ :

$\mathrm{RRD}_{P M(\text { fractions }, i)}=\mathrm{V}_{T} \times \mathrm{BF} \times \mathrm{DF}_{i} \times \mathrm{PM}_{i}$,

where the unit of $R D D_{P M(\text { fractions }, i)}$ is $\mu \mathrm{g} / \mathrm{s}$ and $D F_{i}$ and $P M_{i}$ $\left(\mu \mathrm{g} / \mathrm{m}^{3}\right)$ are the DF and PMC for each of the $i$-th PM fractions, respectively. Moreover, the $D F_{i}$ values are calculated based on the mass median diameter $\left(d_{p}, \mu \mathrm{m}\right)$ of the PM in 


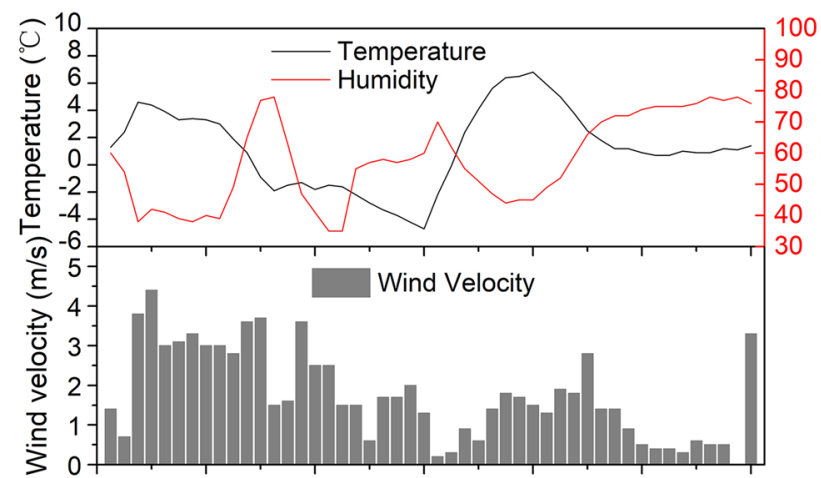

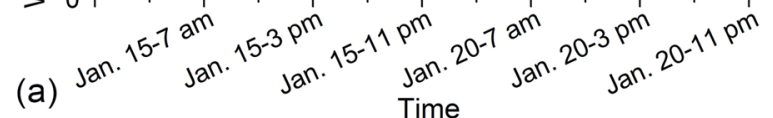
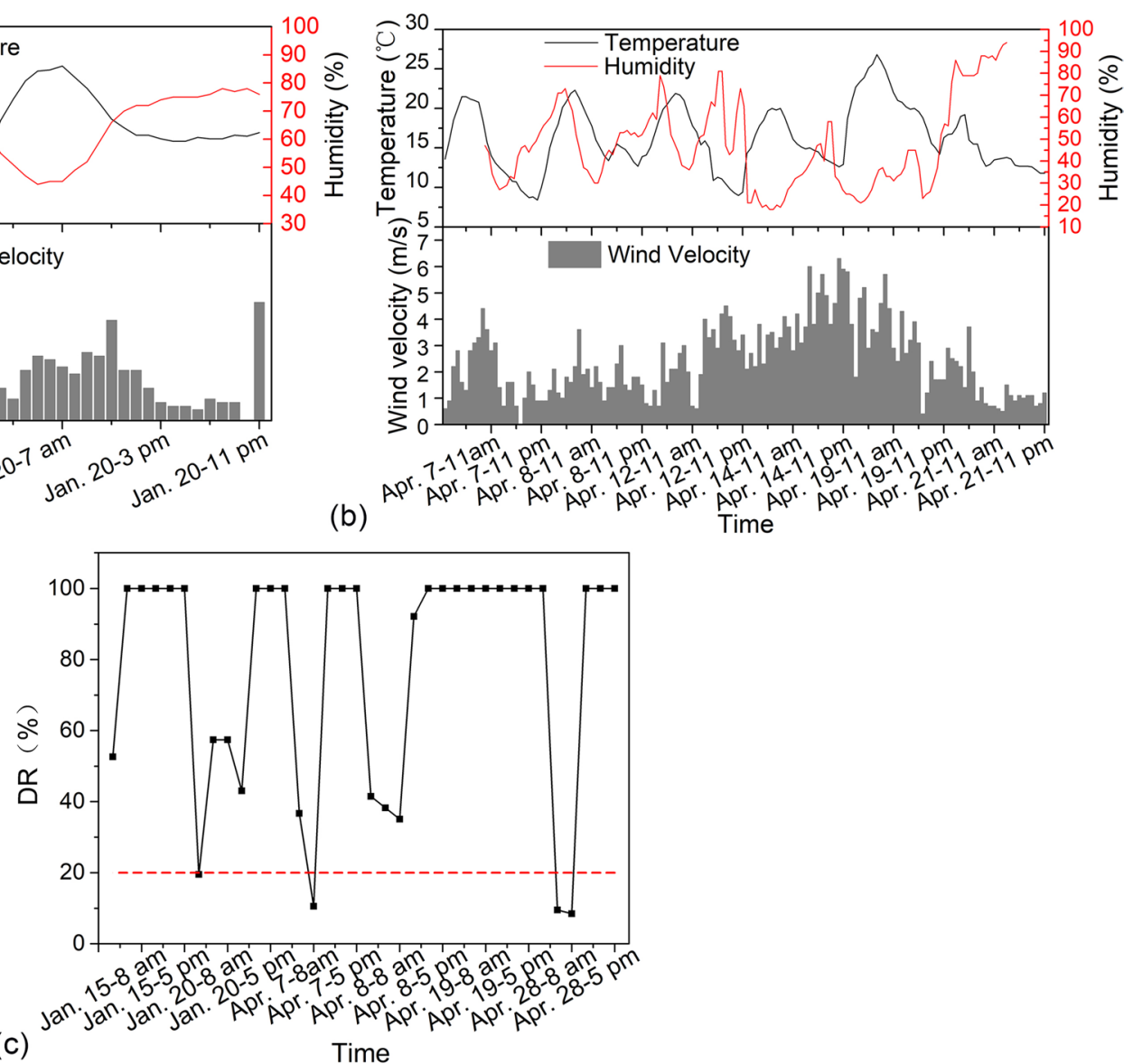

Fig. 4 The weather conditions and draft rate during the test period: a winter; $\mathbf{b}$ spring; $\mathbf{c}$ draft rate

Fig. 5 Test instrument: a particulate concentration collection instrument; b GPS
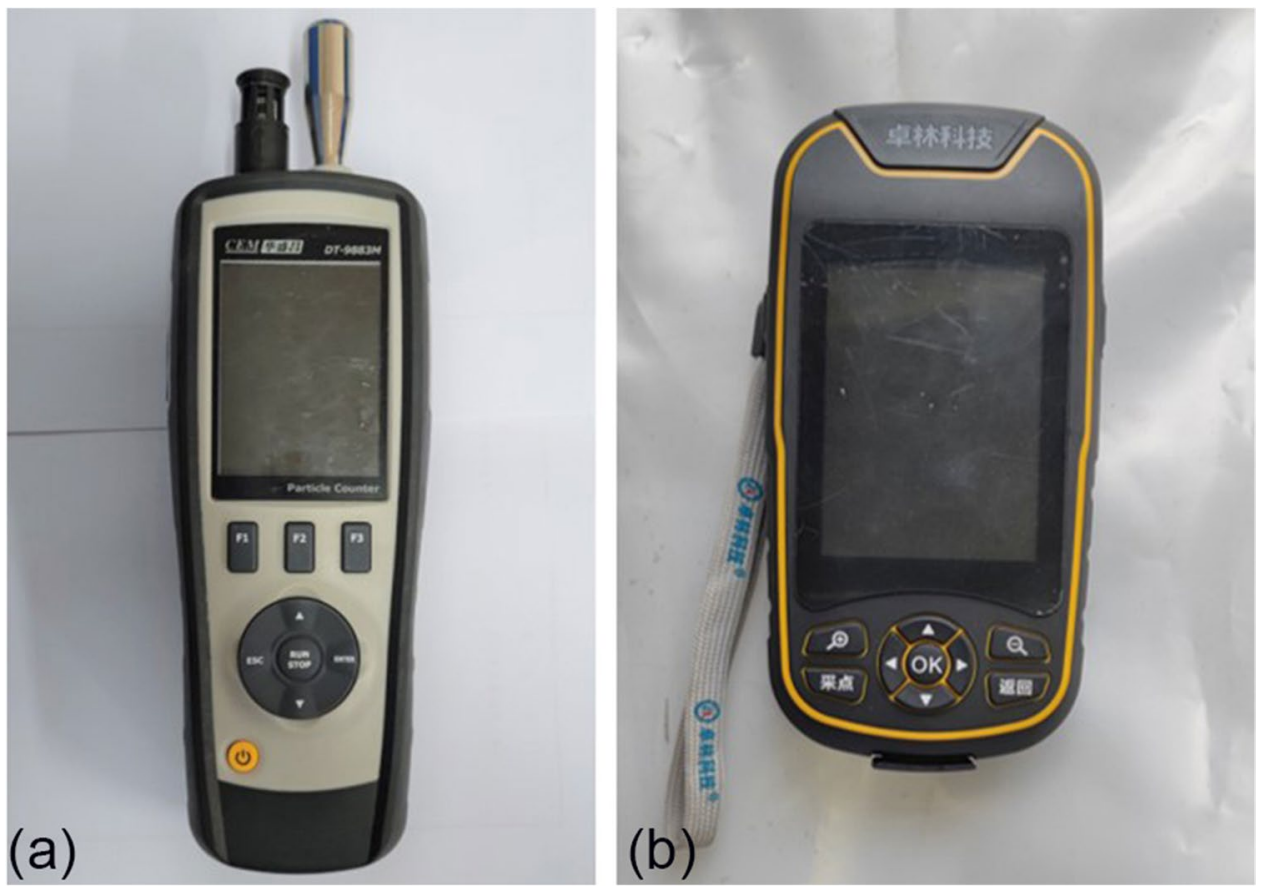
various size ranges (Azarmi and Kumar 2016) using Eqs. (2) and (3), as given by Hinds (Hinds 1999):

$\mathrm{DF}=I F\left(0.058+\frac{0.911}{1+\exp \left(4.77+1.485 \ln d_{p}\right)}+\frac{0.943}{\exp \left(0.508-2.58 \ln d_{p}\right)}\right)$,

where $I F$ is the inhalable fraction, which is calculated by Eq. (3):

$\mathrm{IF}=1-0.5\left(1-\frac{1}{1+0.00076 d_{p}^{2.8}}\right)$,

where $d_{p}$ is the average particle diameter $(\mu \mathrm{m})$, which is based on the mass of the coarse and fine particle fractions.

For males (females) during sitting, light exercise, and heavy exercise, $V_{T}$ is, respectively, equal to 750 (460), 1250 (990), and 1920 (1360) $\mathrm{cm}^{3}$ per breath (Hinds 1999). For males (females), the value of $B F$ is taken as $0.2(0.24), 0.34$ (0.35), and 0.44 (0.55) during sitting, light exercise, and heavy exercise, respectively (Hinds 1999). The students considered in this study walk to and from school, so their exercise level is light exercise. Therefore, for male (female) students, $V_{T}$ was considered to be $1250(990) \mathrm{cm}^{3}$ per breath, and $B F$ was considered to be 0.34 (0.35) breath per second.

IBM SPSS software was used to conduct $T$ tests on the data, and $P<0.05$ indicates statistically significant differences.

\section{Total respiratory deposition dose}

Madureira et al. (2020) used the multiple-path particle dosimetry model to quantify the total respiratory deposition of particulate matter in newborns and mothers. Patterson et al. (2014) evaluated cumulative exposure to UFPs by simulating a 24-h school day exposure period using the number of hours children spend in each microenvironment. To further explore the exposure risk of students during their commute, a new parameter index, namely, the TRDD (total respiratory deposition dose), is introduced according to the ICRP model to calculate the total amount of particulate matter inhaled by students during their annual commuting time. TRDD represents the amount of particulate matter inhaled in a certain period, which is determined by RDD and exposure time. The calculation method of the TRDD is given by the following:

$\mathrm{TRRD}_{P M(\text { fractions })}=R R D_{P M(\text { fractions })} \times T_{e}$,

where $R D D_{P M}$ is calculated by Eq. (1) and $T_{e}$ is the annual commuting exposure time, min.

TRDD index can improve the risk assessment of trafficrelated pollution exposure from a relatively macro-perspective and can uncover the impact of traffic pollution on primary school students during their commute under different traffic conditions over different years. Thus, it can provide guidance for the commuting arrangement of primary school students on a year or semester basis.

\section{Uncertainty analysis}

In order to quantify the accuracy of measurements, an uncertainty analysis of the measured data is carried out based on the General Law of Uncertainty Propagation (ISO. 1995). The uncertainty can be obtained by the following equations (Mathioulakis et al. 1999), and results are listed in Table 3.

$$
\begin{gathered}
u_{i}=\left(\frac{w_{i}^{2}}{3}\right)^{0.5} \\
U_{R}=\left(\sum_{i=1}^{n} u_{i}^{2}\right)^{0.5}=\left(\frac{1}{3} \sum_{i=1}^{n} w_{i}^{2}\right)^{0.5}
\end{gathered}
$$

where $u_{i}$ is the standard uncertainty of measured parameter; $w_{i}$ is the accuracy of device; and $U_{R}$ is the standard uncertainty of the parameter determined by other measured parameters.

\section{Results}

The concentrations of $\mathrm{PM}_{2.5}$ and $\mathrm{PM}_{10}$ along different commuting routes around a primary school during different commuting periods were tested in the field and relatively accurate and true pollutant data reflecting the exposure environment of primary school students were obtained. The concentrations of particulate matter on different routes during the test period were analyzed and compared with data from the background monitoring site. The distributions of particulate matter at different locations along different routes can be intuitively observed via the resulting spatial distribution diagrams. To assess the exposure of primary school students, the RDD values under various conditions were calculated, based on which the TRDD during the annual commuting period was calculated.

\section{Particulate matter concentrations during the measurement}

Figure 6 presents the concentrations of particulate matter at different times in winter, from which it is evident that the concentrations of particulate matter in winter were always at a high level. During the winter measurement,

Table 3 Accuracy and uncertainty of measured parameters

\begin{tabular}{llll}
\hline Parameters & Devices & Accuracy & Uncertainty \\
\hline $\mathrm{PM}_{2.5}$ concentration & CEM DT-9883 M & $\pm 1 \mu \mathrm{g} / \mathrm{cm}^{3}$ & $0.58 \mu \mathrm{g} / \mathrm{cm}^{3}$ \\
$\mathrm{PM}_{10}$ concentration & CEM DT-9883 M & $\pm 1 \mu \mathrm{g} / \mathrm{cm}^{3}$ & $0.58 \mu \mathrm{g} / \mathrm{cm}^{3}$ \\
\hline
\end{tabular}



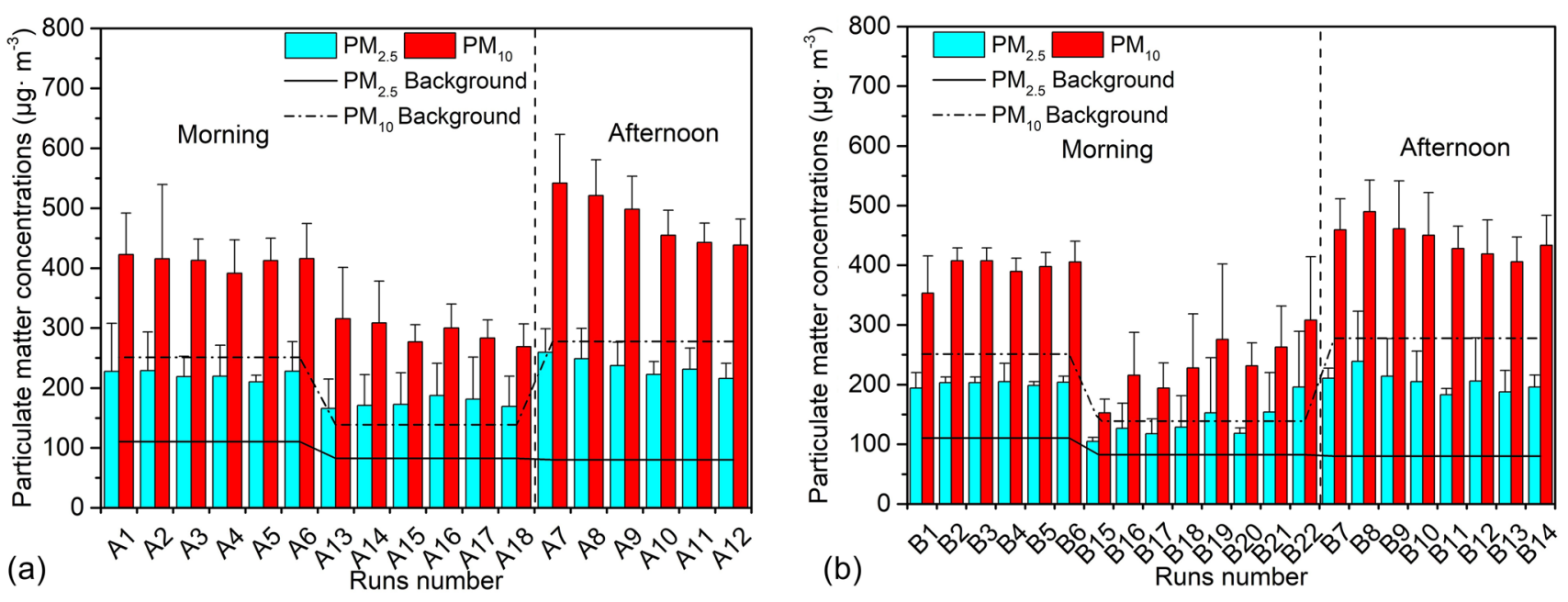

Fig. 6 The comparison of pollutant concentrations at different times in winter: a route A; $\mathbf{b}$ route B

the concentration of $\mathrm{PM}_{2.5}$ ranged from 104.8 to $259.6 \mu \mathrm{g} /$ $\mathrm{m}^{3}$, while that of $\mathrm{PM}_{10}$ ranged from 152.7 to $542.0 \mu \mathrm{g} / \mathrm{m}^{3}$. The lowest measured concentrations of $\mathrm{PM}_{2.5}$ and $\mathrm{PM}_{10}$ all appeared along route $\mathrm{B}$. Along route $\mathrm{A}$, the $\mathrm{PM}_{2.5}$ and $\mathrm{PM}_{10}$ concentrations in the afternoon in winter were found to be respectively increased by 38.8 and $132.8 \mu \mathrm{g} / \mathrm{m}^{3}$ as compared with the concentrations in the morning, and the concentration of coarse particles was 3.4 times that of fine particles. Along route $\mathrm{B}$, the $\mathrm{PM}_{2.5}$ and $\mathrm{PM}_{10}$ concentrations in the afternoon in winter were found to be respectively increased by 41.3 and $238.3 \mu \mathrm{g} / \mathrm{m}^{3}$ as compared with the concentrations in the morning.

As is shown in Fig. 7, the concentration of particulate matter in spring was significantly lower than that in winter. During the spring measurement, the $\mathrm{PM}_{2.5}$ concentration ranged from 12.1 to $176.2 \mu \mathrm{g} / \mathrm{m}^{3}$, and the $\mathrm{PM}_{10}$ concentration ranged from 35.5 to $365.4 \mu \mathrm{g} / \mathrm{m}^{3}$. Similar to the winter, the lowest measured concentrations of $\mathrm{PM}_{2.5}$ and $\mathrm{PM}_{10}$ all appeared along route $\mathrm{B}$. The temporal variation of $\mathrm{PMC}$ in spring was not consistent with that in winter. In spring, the average concentrations of $\mathrm{PM}_{2.5}$ and $\mathrm{PM}_{10}$ on route $\mathrm{A}$ in the afternoon were 41.3 and $87.1 \mu \mathrm{g} / \mathrm{m}^{3}$ lower than those in the morning, respectively. Moreover, the average concentrations of $\mathrm{PM}_{2.5}$ and $\mathrm{PM}_{10}$ on route B were 21.9 and $50.6 \mu \mathrm{g} /$ $\mathrm{m}^{3}$ lower than those in the morning, respectively, which is related to the climatic characteristics of Jinan in spring.

The average concentrations of particulate matter at different times along different routes, as well as the concentrations collected at the background monitoring station, are reported in Table 4. The results of Shapiro-Wilk Test showed that the data obeyed normal distribution (Shapiro and Francia 1972). $T$-tests were carried out on the measured data during data processing, and the results were found to be statistically significant. According to the data, the particulate matter concentrations on route $\mathrm{A}$ were higher than those on route $B$ in different seasons and at different times. In winter, the concentrations of particulate matter along the two routes were higher than those determined by the background monitoring site, and the highest concentration was 2.94 times the background monitoring value. The $\mathrm{PM}_{2.5}$ concentration in winter as determined by the background monitoring station was lower in the afternoon than in the morning, while the background $\mathrm{PM}_{10}$ concentration was higher in the afternoon than in the morning, and the measured values were all higher in the afternoon than in the morning. In spring, the measured average concentrations of $\mathrm{PM}_{10}$ on routes $\mathrm{A}$ and $\mathrm{B}$ in the afternoon were respectively 25.4 and $28.3 \mu \mathrm{g} / \mathrm{m}^{3}$ lower than the background values. The measured values at other times were still higher than the background values. In the afternoon, students' commuting time is often earlier than the evening rush hour in the city, and the increase in the particulate matter concentration along the traffic routes around the school is not detectible by background monitoring stations.

The ratio of the actual measured particulate concentration to the background data is represented by $C_{a / b}$, and the specific relationship is presented in Fig. 8. In winter, the average concentrations of $\mathrm{PM}_{2.5}$ and $\mathrm{PM}_{10}$ on route $\mathrm{A}$ were 2.4 and 1.8 times higher than those at the background monitoring site, and those on route B were 2.0 and 1.6 times higher than those at the background monitoring site. In spring, the average concentrations of PM2.5 and PM10 on route A were 1.8 and 1.8 times higher than those at the background monitoring site, and those on route B were 1.4 and 1.4 times higher than those at the background monitoring site. The decrease of the $\mathrm{PM}_{2.5}$ concentration in spring is obvious and corresponds to the decrease of traffic flow for picking up and dropping off students in spring (Xiao et al. 2019; Zhao et al. 2019). In winter, the average concentration 

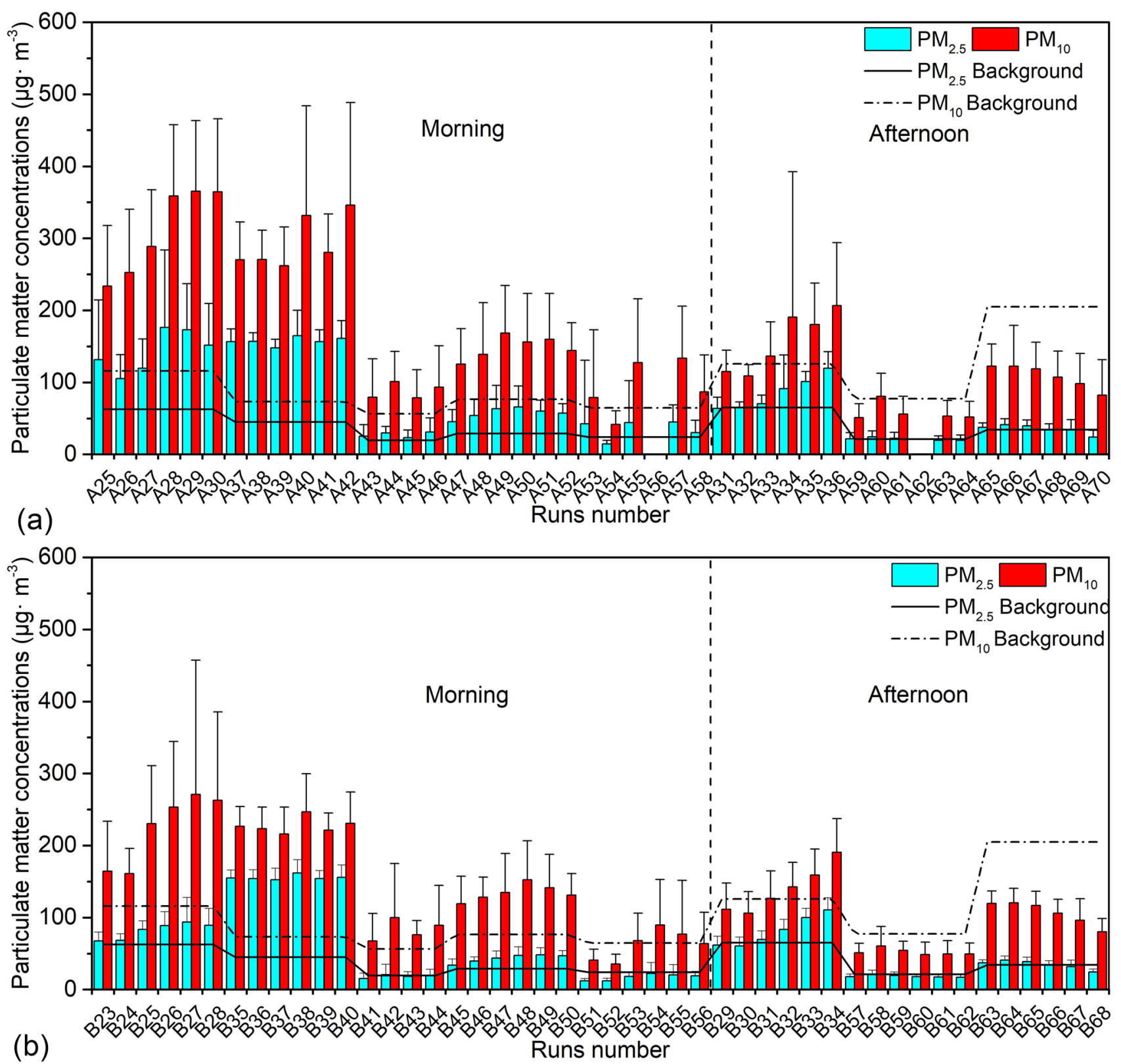

Fig. 7 The comparison of pollutant concentrations at different times in spring: a route A; b route B

of $\mathrm{PM}_{2.5}$ on route $\mathrm{A}$ was 1.19 times that on route $\mathrm{B}$ in the morning $(P=0.000)$ and 1.14 times that on route $\mathrm{B}$ in the afternoon $(P=0.012)$. Moreover, in winter, the average concentration of $\mathrm{PM}_{10}$ on route $\mathrm{A}$ was 1.11 times that on route $\mathrm{B}$ in the morning $(P=0.001)$ and 1.08 times that on route $\mathrm{B}$ in the afternoon $(P=0.000)$. In spring, the average $\mathrm{PM}_{2.5}$ concentration on route A was 1.3 times that on route $\mathrm{B}$ in the morning $(P=0.000)$ and 1.02 times that on route $\mathrm{B}$ in the afternoon $(P=0.012)$. Furthermore, in spring, the average $\mathrm{PM}_{10}$ concentration on route $\mathrm{A}$ was 1.25 times that on route $\mathrm{B}$ in the morning $(P=0.000)$ and 1.03 times that on route $\mathrm{B}$ in the afternoon $(P=0.012)$. By comparison, it can be determined that the particulate matter concentration on route $\mathrm{B}$ was lower than that on route $\mathrm{A}$ in both seasons. Thus, choosing a route away from the main road will expose students to lower levels of traffic pollution.

\section{Spatial variation of particulate matter concentrations}

To provide a more intuitive comparison of the changes in the concentration of particulate matter along different routes and at different positions on the same route, Figs. 9 and 10 present the cloud maps of the changes in the concentrations of 
Table 4 The comparison of the average particulate matter concentrations with the background values

\begin{tabular}{|c|c|c|c|c|c|c|c|}
\hline \multirow[t]{2}{*}{ Season } & \multirow[t]{2}{*}{ Time } & & \multicolumn{5}{|l|}{$\mathrm{PMC}\left(\mu \mathrm{g} / \mathrm{m}^{3}\right)$} \\
\hline & & & Background & Route A & $\begin{array}{l}\text { Average } \\
\text { Difference }\end{array}$ & Route B & $\begin{array}{l}\text { Average } \\
\text { Differ- } \\
\text { ence }\end{array}$ \\
\hline \multirow[t]{4}{*}{ Winter } & \multirow[t]{2}{*}{ Morning } & $\mathrm{PM}_{2.5}$ & \multicolumn{2}{|c|}{$96.3 \pm 14.1197 .2 \pm 51.1$} & 100.9 & $166.1 \pm 35.0$ & 69.8 \\
\hline & & $\mathrm{PM}_{10}$ & \multicolumn{2}{|c|}{$194.8 \pm 56.2350 .2 \pm 56.3$} & 155.4 & $312.8 \pm 61.9$ & 118 \\
\hline & \multirow[t]{2}{*}{ Afternoon } & $\mathrm{PM}_{2.5}$ & \multicolumn{2}{|c|}{$80.3 \pm 8.8236 .0 \pm 35.2$} & 155.7 & $207.4 \pm 50.0$ & 127.1 \\
\hline & & $\mathrm{PM}_{10}$ & \multicolumn{2}{|c|}{$277.7 \pm 58.4483 .0 \pm 52.1$} & 205.3 & $445.4 \pm 57.4$ & 167.7 \\
\hline \multirow[t]{4}{*}{ Spring } & Morning & $\mathrm{PM}_{2.5}$ & $40 \pm 15.9$ & $90.0 \pm 32.6$ & 50 & $69.2 \pm 14.1$ & 29.2 \\
\hline & \multirow{3}{*}{ Afternoon } & $\mathrm{PM}_{10}$ & \multicolumn{2}{|c|}{$96.6 \pm 22.1197 .7 \pm 71$} & 101.1 & $158.3 \pm 60.1$ & 61.7 \\
\hline & & $\mathrm{PM}_{2.5}$ & \multicolumn{2}{|c|}{$40.1 \pm 22.1 \quad 48.7 \pm 12.5$} & 8.6 & $47.3 \pm 9.6$ & 7.2 \\
\hline & & $\mathrm{PM}_{10}$ & $136 \pm 53.4$ & $110.6 \pm 47.7$ & -25.4 & $107.7 \pm 31.4$ & -28.3 \\
\hline
\end{tabular}

Runs number

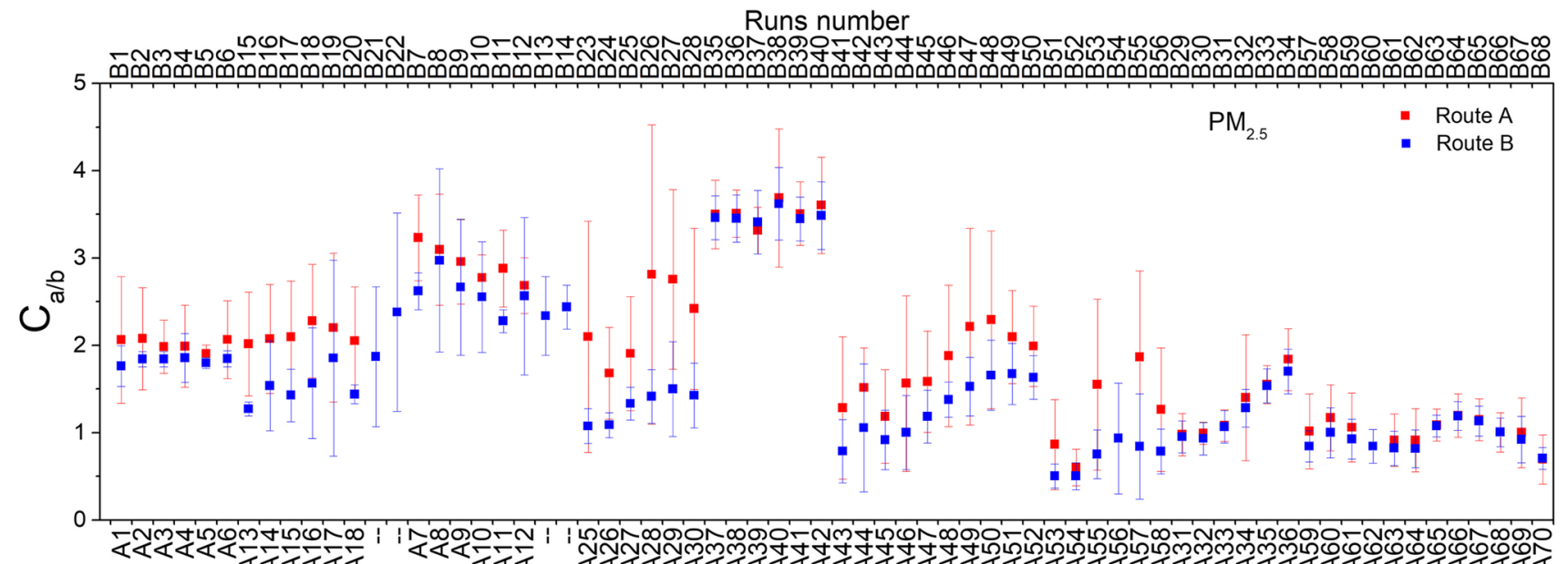

(a)
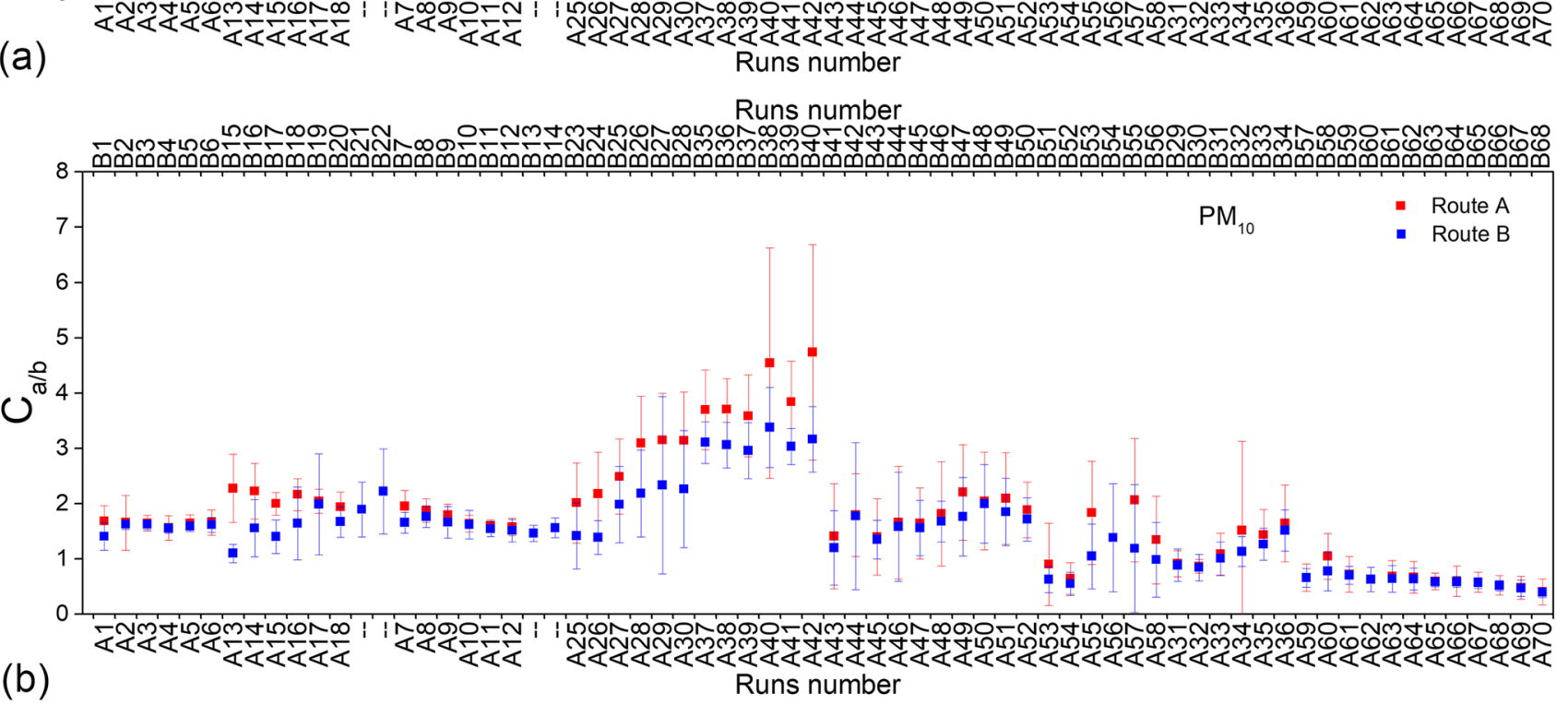

Fig. 8 The ratios of the actual particulate matter concentration to the background concentration $\left(C_{a / b}\right): \mathbf{a} \mathrm{PM}_{2.5} ; \mathbf{b} \mathrm{PM}_{10}$

particulate matter in different seasons and at different times. For winter, runs $\mathrm{A} 1$ and $\mathrm{B} 1$ in the morning and runs $\mathrm{A} 7$ and B7 in the afternoon were selected. For spring, runs A25 and
B23 in the morning and runs A59 and B57 in the afternoon were chosen. The test periods of these sample routes were the same, and the concentrations of particulate matter were 


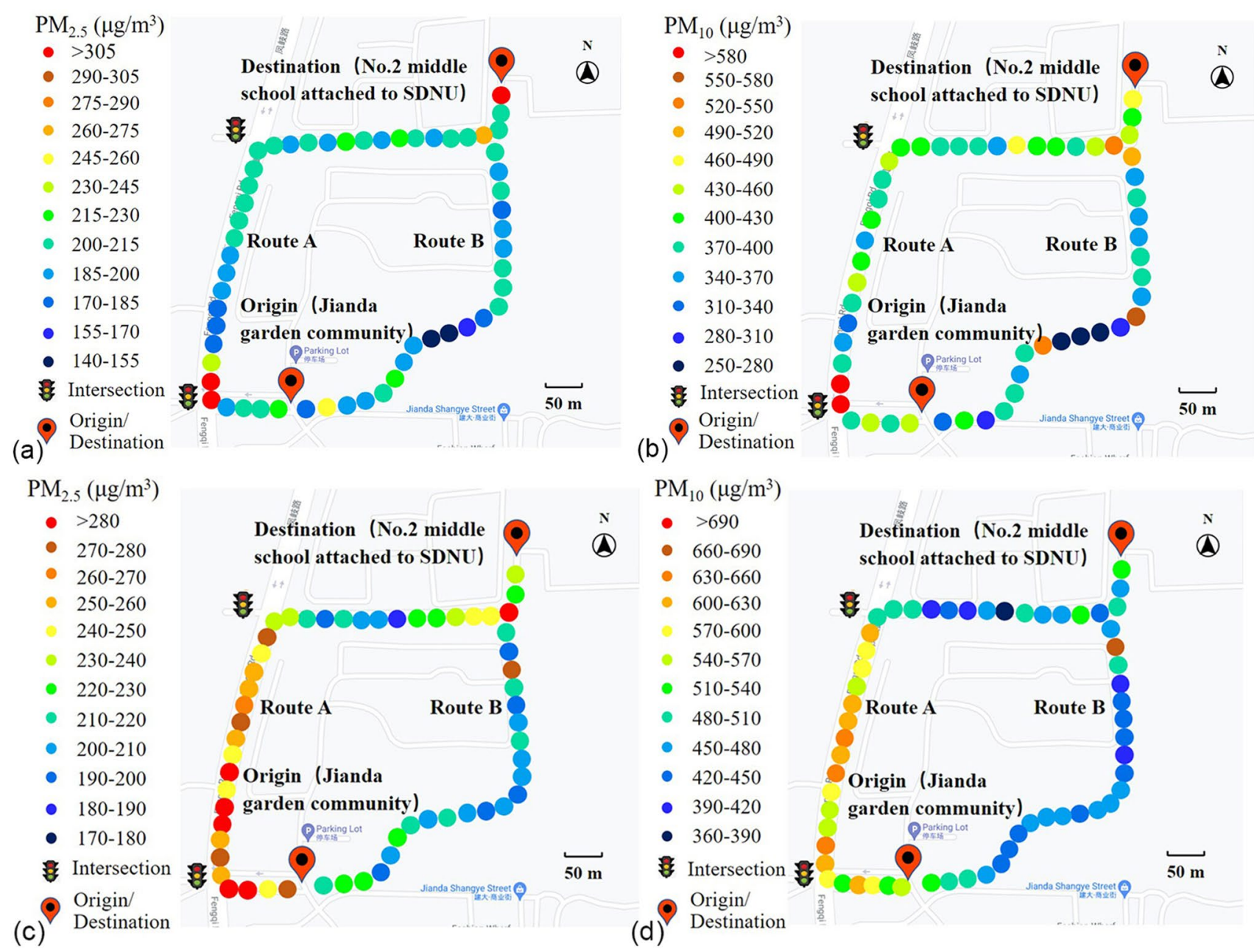

Fig. 9 The comparison of the pollution status of different routes in winter: $\mathbf{a} \mathrm{PM}_{2.5}$ in the morning (taking $\mathrm{A} 1$ as an example); $\mathbf{b}$ PM 10 in the morning (taking B1 as an example); $\mathbf{~ P M}_{2.5}$ in the afternoon (taking A7 as an example); $\mathbf{d} \mathrm{PM}_{10}$ in the afternoon (taking B7 as an example)

close to the average levels. Thus, the test environment could represent the daily living environment.

As can be seen from Fig. 9, in winter, the concentrations of $\mathrm{PM}_{2.5}$ and $\mathrm{PM}_{10}$ on route $\mathrm{A}$ were higher than those on route $\mathrm{B}$, which is also proven by the data reported in the "Particulate matter concentrations during the measurement" section. The concentrations of $\mathrm{PM}_{2.5}$ and $\mathrm{PM}_{10}$ at the entrance of the residential area, i.e., at the traffic lights near the origin, were higher than those at other places. This is because this is the access hub at which vehicles are waiting at idle speed, thereby resulting in sharp increases in the concentrations of particulate matter up to $514 \mu \mathrm{g} / \mathrm{m}^{3}\left(\mathrm{PM}_{2.5}\right)$ and $629.5 \mu \mathrm{g} / \mathrm{m}^{3}\left(\mathrm{PM}_{10}\right)$, which are respectively 4.7 and 251 times the background values. The particulate matter concentrations of the main road section (section $A_{b}$ ) on route $A$ were significantly higher than those at other sections, as is evident from Fig. 9c and d. This is mainly due to the large traffic flow in section $A_{b}$ and the existence of traffic lights; this leads to vehicle congestion and idle operation, which causes traffic-related pollutants to gather around the road and spread to the walking area. It takes approximately $5 \mathrm{~min}$ for students to walk along this section. According to Eq. (1), in a single trip along this section, students will inhale at least $10 \mu \mathrm{g}$ of $\mathrm{PM}_{2.5}$, which will remain in their lungs for at least 3 months (Hinds 1999). This poses a serious threat to the health of the students' lungs (Peng et al. 2019). Although the concentrations of particulate matter on both routes exceeded the standards, the concentrations of only a few locations on route $\mathrm{B}$ exceeded those on route $\mathrm{A}$.

As can be seen from Fig. 10, the concentrations of particulate matter on the two routes in spring were decreased as compared with those in winter, and the low-concentration distribution area along the entire route was significantly higher in spring than in winter. However, increased pollutant concentrations caused by congestion at the gate of the community were still found to exist. As compared to that in winter, the proportional area with high concentrations of pollutants in section $\mathrm{Ab}$ decreased in spring, which was 


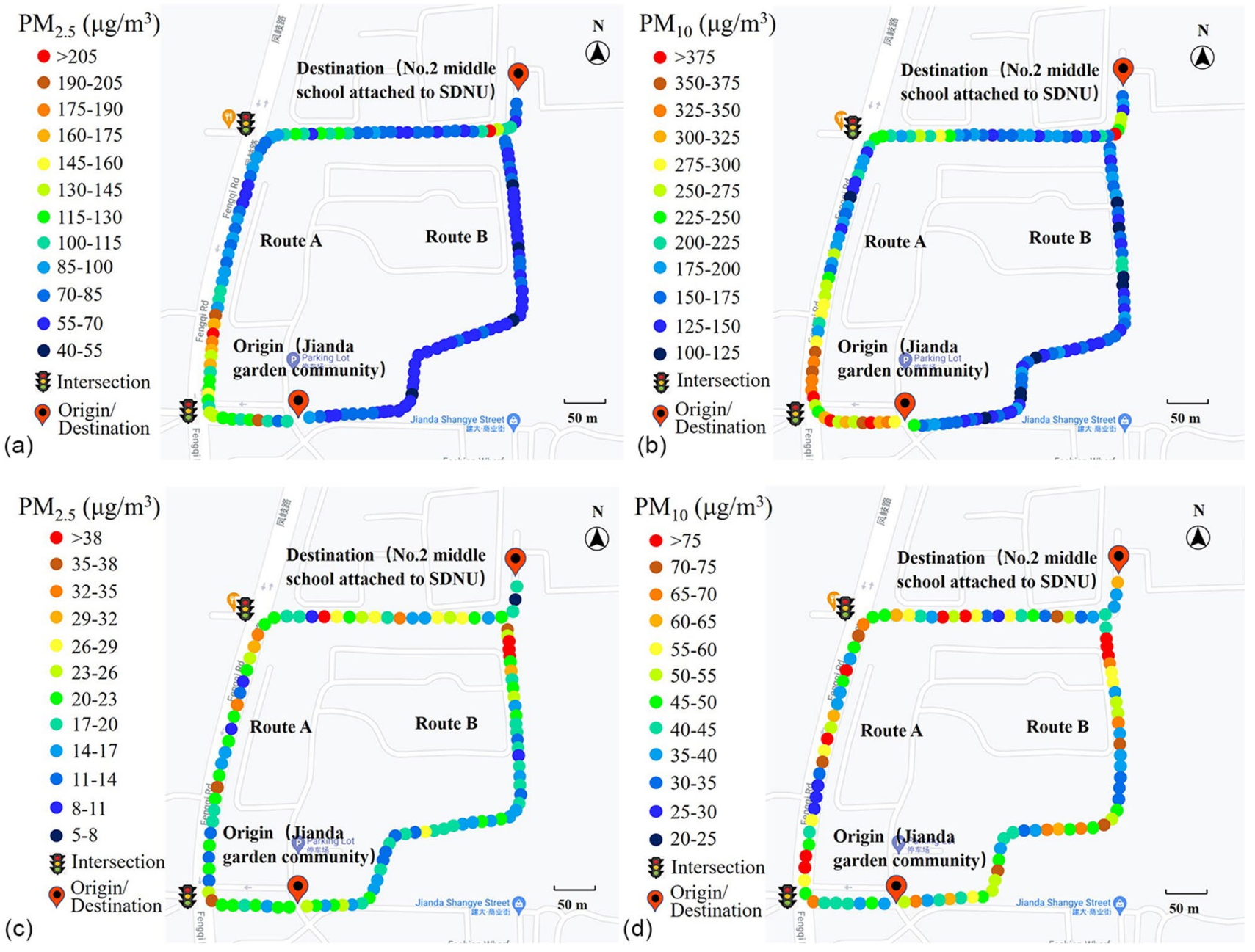

Fig. 10 The comparison of the pollution status of different routes in spring: $\mathbf{P M}_{2.5}$ in the morning (taking $\mathrm{A} 25$ as an example); $\mathbf{b}$ PM 10 in the morning (taking B23 as an example); PM $_{2.5}$ in the afternoon (taking A59 as an example); $\mathbf{d} \mathrm{PM}_{10}$ in the afternoon (taking B57 as an example)

due to the obvious decrease of traffic flow in spring and the decrease in the number of idle vehicles on the road. Furthermore, the existence of breezes during the spring measurements was also a reason for the reduction of the accumulation of particles.

In sections $A_{c}$ and $A_{d}$, the concentrations of particulate matter exceeded those in section $A_{b}$ on the main road (Fig. 10d, Figs. SI 1a and SI 1d, Fig. SI 3). This is because sections $A_{c}$ and $A_{d}$ are located in a building complex, and the airflow in the street canyon is hindered; this causes the short-term accumulation of particulate matter at the leeward side, resulting in the increase of pollutant concentrations. As shown in Figs. 10c and d, at the intersection of the end points of routes $\mathrm{A}$ and $\mathrm{B}$, the concentrations of particulate matter were found to suddenly increase, which was caused by the indoor stairwell. Some dust accumulated in the stairwell, and when the number of pedestrians increased, the amount of dust increased. However, when the students stayed in the stairwell for less than $1 \mathrm{~min}$, the maximum amount of $\mathrm{PM}_{2.5}$ inhaled during this time was less than $4 \mu \mathrm{g}$, which was less than the amount of $\mathrm{PM}_{2.5}$ inhaled in the section with the highest pollutant concentration on route $\mathrm{A}(10 \mu \mathrm{g})$. The dust control measurement of staircases is relatively easy to achieve, and as shown in Fig. SI 3, after simple sprinkling measures were taken, the points of high particulate matter concentrations disappeared. In general, route B has fewer areas with high particulate matter concentrations, and the overall exposure risk is less than that of route $\mathrm{A}$.

\section{Exposure assessment}

The RDD is adapted from the ICRP model; it represents the amount of particulate matter inhaled by the respiratory system and is widely used in the assessment of inhaled doses of pollutants. It is suitable for the analysis of particles with uniform particle size and does not require the calculation of the specific deposition area. Figure 11 first compares the RDD of $\mathrm{PM}_{2.5}\left(R D D_{P M 2.5}\right)$ of male and female students in different 


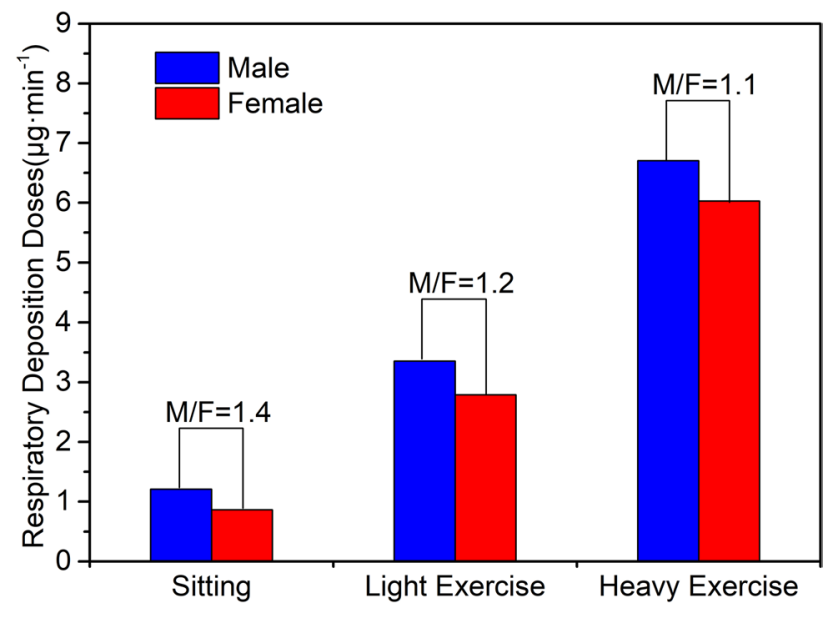

Fig. 11 The comparison of the $R D D_{P M 2.5}$ values of males and females under different exercise states

exercise states, taking the average $\mathrm{PM}_{2.5}$ concentration of run A1 as an example. The selection of the relevant parameters was explained in the "Total respiratory deposition dose" section. It can be seen from the figure that the $R D D_{P M 2.5}$ value of males is higher than that of females in the three exercise states, but the proportion is different. The students considered in this study walk to school, which is considered light exercise. In the following analysis, the RDD values of males are taken as an example by default (Kumar et al. 2017), and the RDD values of females can be calculated as the RDD values of males divided by 1.2 .

As shown in Figs. 12 and 13, in winter, the $R D D_{P M 2.5}$ and $R D D_{P M 10}$ values on route $\mathrm{A}$ in the morning were, respectively, 2.4-3.4 and 6.3-9.8 $\mu \mathrm{g} / \mathrm{min}$; in the afternoon, these values were, respectively, $3.2-3.8$ and $10.2-12.6 \mu \mathrm{g} / \mathrm{min}$. On route $\mathrm{B}$ in winter, the $R D D_{P M 2.5}$ and $R D D_{P M 10}$ values in the morning were, respectively, $1.6-3.0$ and 3.5-9.5 $\mu \mathrm{g} / \mathrm{min}$; in the afternoon, these values were, respectively, 2.7-3.5 and $9.7-11.4 \mu \mathrm{g} / \mathrm{min}$. In winter, while the variation range of the RDD values on route $A$ was greater than that on route $B$ in the morning, the opposite relationship was found in the afternoon.

In spring, the $R D D_{P M 2.5}$ and $R D D_{P M 10}$ values on route A were, respectively, $0.7-2.6$ and $2.9-8.5 \mu \mathrm{g} / \mathrm{min}$; in the afternoon, these values were, respectively, 0.3-1.8 and $1.2-4.8 \mu \mathrm{g} / \mathrm{min}$. On route $\mathrm{B}$ in spring, the $R D D_{P M 2.5}$ and $R D D_{P M 10}$ values in the morning were, respectively, 0.5-1.4 and $2.8-6.3 \mu \mathrm{g} / \mathrm{min}$; in the afternoon, these values were, respectively, $0.2-1.6$ and $0.99-4.4 \mu \mathrm{g} / \mathrm{min}$, respectively. Compared with those in winter, the variation ranges of the RDD values were found to be increased in spring. In spring, the $R D D_{P M 2.5}$ values of the two routes in the afternoon were similar, indicating that the effect of traffic on the increase of the $\mathrm{PM}_{2.5}$ concentration was less than that of wind during the commuting time in the afternoon.
On average, as shown in Fig. $14 \mathrm{a}$, in winter, the $R D D_{\mathrm{PM} 2.5}$ and $R D D_{\mathrm{PM} 10}$ values on route $\mathrm{A}$ in the morning were, respectively, 0.5 and $1.1 \mu \mathrm{g} / \mathrm{min}$ higher than those on route $\mathrm{B}$, and in the afternoon, the values were, respectively, 0.4 and $0.7 \mu \mathrm{g} / \mathrm{min}$ higher. The advantage of route $\mathrm{B}$ is more obvious in the morning in winter; by comparing the RDD values of the two routes in different seasons, it is evident that the RDD values on route $B$ were always lower than those on route $A$, which indicates that route $B$ is more suitable for students to walk.

As shown in Fig. 15, the $\mathrm{RDDPM}_{2.5}$ was taken as an example to show the students' PM2.5 respiratory deposition dose at the background particulate concentration and measured particulate concentration, and corresponding to the wind velocity during the test. The overall respiratory deposition dose included the effects of ambient particulate matter and current traffic-related particulate matter, both of which were affected by weather to some extent. According to the calculation results of background monitoring station data, it can be seen that the respiratory deposition dose caused by background particulate pollution was less than the overall respiratory deposition dose in most of the time, especially in winter.

It should also be noted that the concentration of background particulate matter in winter was a great threat to students' health, while traffic activities greatly increased the exposure risk of students during commuting time. The effect of wind speed on particulate distribution was worth considering as an important parameter. For the tests conducted on the same day, it is found that when wind speed increased in spring, particulate concentration and exposure risk decreased. When the wind speed was low in winter, the alleviating effect of severe pollution was not obvious.

\section{Analysis of total respiratory deposition dose}

According to the actual measurement process, it takes approximately $11 \mathrm{~min}$ to complete either route $\mathrm{A}$ or $\mathrm{B}$. The numbers of school days in 2018 and 2019 were counted, and due to the impact of COVID-19, the planned number of school days in 2020 was considered. The concentrations of background particulate matter used for calculation and the actual school days are shown in SI 5. The concentrations of $\mathrm{PM}_{2.5}$ and $\mathrm{PM}_{10}$ required in this part of the calculation were determined by backward extrapolation from the relationship between the measured data and the background data reported in the "Particulate matter concentrations during the measurement" section. In winter, the ratios of the mean concentrations of particulate matter on route $A$ to the background concentration were $2.36\left(\mathrm{PM}_{2.5}, P=0.000\right)$ and $1.83\left(\mathrm{PM}_{10}, P=0.000\right)$. Moreover, in winter, the ratios of the mean concentrations of particulate matter on route $B$ to the background concentration were $2.03\left(\mathrm{PM}_{2.5}, P=0.000\right)$ and 

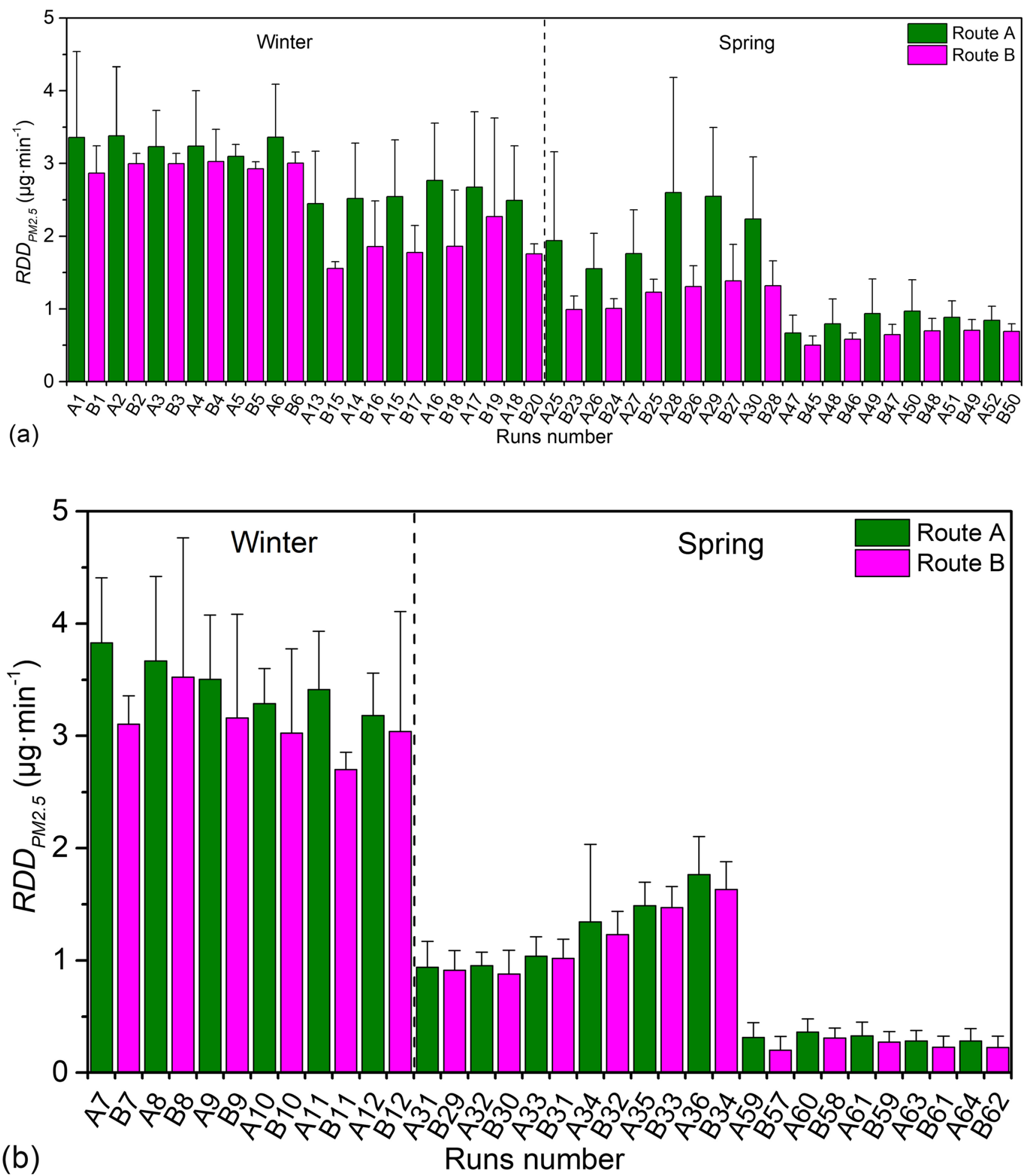

Fig. 12 The comparison of the $R D D_{P M 2.5}$ values in different seasons, at different times, and on different routes: $\mathbf{a}$ morning; $\mathbf{b}$ afternoon

$1.62\left(\mathrm{PM}_{10}, P=0.000\right)$. In spring, the ratios of the average concentrations of particulate matter on route A to the background concentration were $1.76\left(\mathrm{PM}_{2.5}, P=0.000\right)$ and 1.80 $\left(\mathrm{PM}_{10}, P=0.000\right)$. Furthermore, in spring, the ratios of the average concentrations of particulate matter on route $\mathrm{B}$ to the background concentration were $1.40\left(\mathrm{PM}_{2.5}, P=0.008\right)$ and $1.44\left(\mathrm{PM}_{10}, P=0.018\right)$. The ratios to the background concentrations in autumn and summer were calculated via 

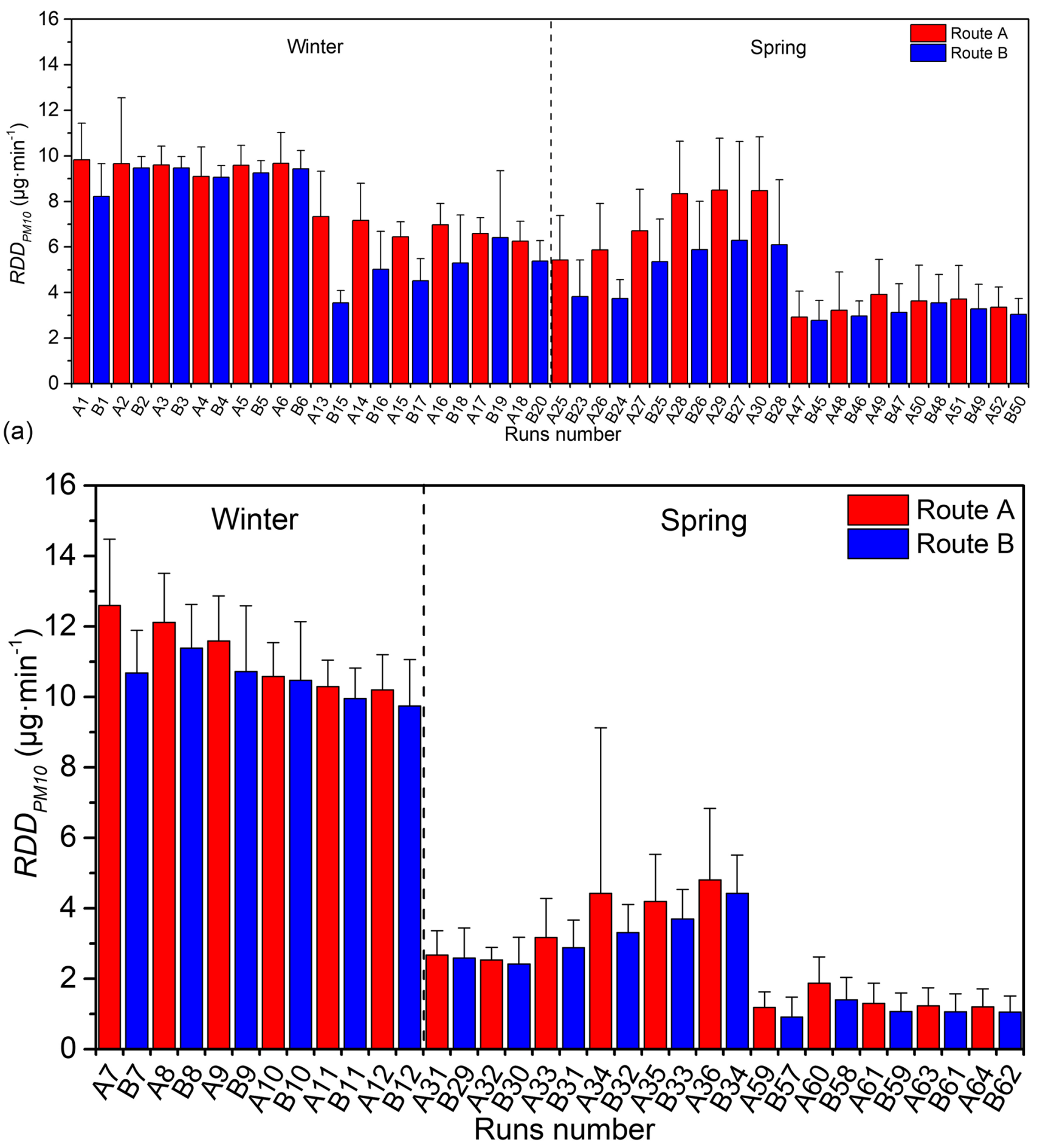

Fig. 13 The comparison of the $R D D_{\mathrm{PM} 10}$ values in different seasons, at different times, and along different routes: a morning; b afternoon

the average values in winter and spring, and the results are reported in Table 5 .

According to the calculation results, the average annual amounts of $\mathrm{PM}_{2.5}$ and $\mathrm{PM}_{10}$ inhalation in 3 years on route A were respectively found to be 7018 and $19,660 \mu \mathrm{g}$, and those on route B were respectively 5874 and 16,543.5 $\mu \mathrm{g}$. The amount of particulate matter inhaled on route $A$ was found to be significantly higher than that on route $\mathrm{B}$. The difference between the two routes was $1144 \mu \mathrm{g}$, which accounted for $16.3 \%$ of the inhalation on route A. It is evident that in the long run, the selection of route $\mathrm{B}$ will greatly reduce $\mathrm{PM}_{2.5}$ inhalation. Due to the impact of COVID-19 in 2020, the traffic 

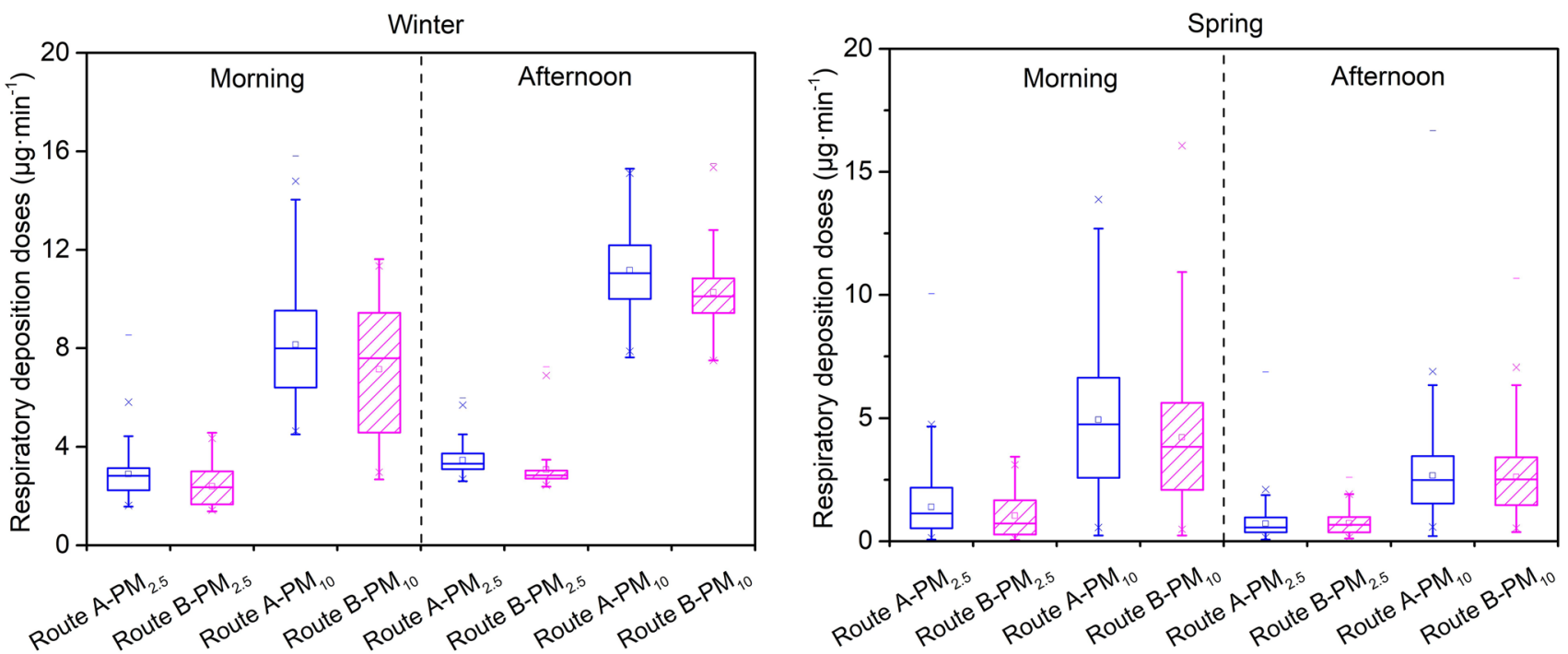

(a)

(b)

Fig. 14 The variation range of the RDD on routes A and B in different seasons: a winter; $\mathbf{b}$ spring

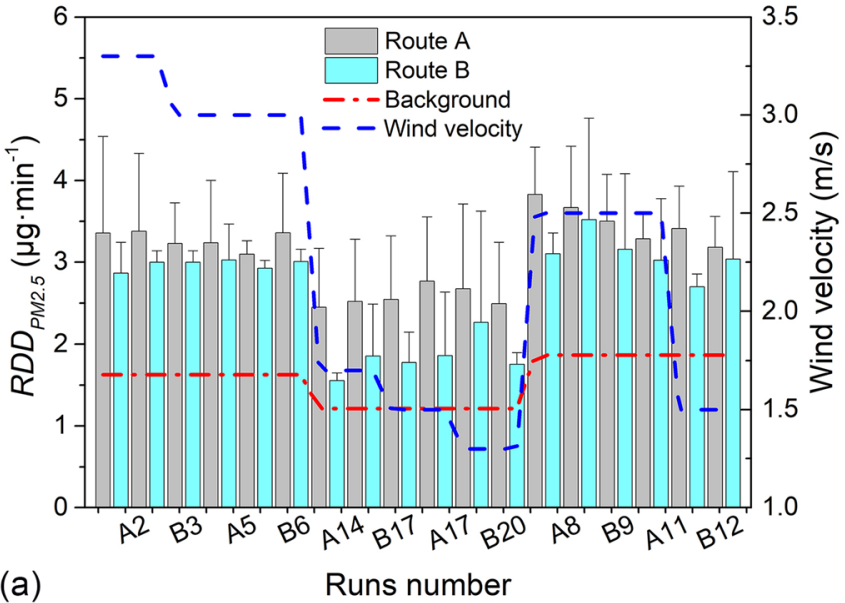

Fig. 15 The variation range of the $R D D_{\mathrm{PM} 2.5}$ and corresponding wind velocity in different seasons and backgrounds: a winter; $\mathbf{b}$ spring
Table 5 The annual inhalation of particulate matter during commuting from 2018 to 2020

\begin{tabular}{lllll}
\hline Year & $\mathrm{PM}$ & Route A $(\mu \mathrm{g})$ & Route B $(\mu \mathrm{g})$ & Difference $(\mu \mathrm{g})$ \\
\hline 2018 & $\mathrm{PM}_{2.5}$ & 6854 & 5736 & 1118 \\
& $\mathrm{PM}_{10}$ & 19430 & 16378 & 3052 \\
2019 & $\mathrm{PM}_{2.5}$ & 7446 & 6234 & 1212 \\
& $\mathrm{PM}_{10}$ & 21090 & 17744 & 3346 \\
2020 & $\mathrm{PM}_{2.5}$ & 6326 & 5292 & 1034 \\
& $\mathrm{PM}_{10}$ & 17030 & 14308 & 2722 \\
\multirow{2}{*}{ Mean } & $\mathrm{PM}_{2.5}$ & 7018 & 5874 & 1144 \\
& $\mathrm{PM}_{10}$ & 19660 & 16543.5 & 3116.5 \\
\hline
\end{tabular}

flow in the most recent half a year was lower than that in the previous 2 years (Zhou et al. 2022). The comparison of the inhalation of $\mathrm{PM}_{2.5}$ and $\mathrm{PM}_{10}$ over 3 years showed that the average amounts of $\mathrm{PM}_{2.5}$ and $\mathrm{PM}_{10}$ inhalation in 2020 were respectively $11.1 \%$ and $14.7 \%$ lower than those in the previous 2 years, which proves the contribution of traffic to the increase of particulate matter concentrations. 


\section{Discussion}

The research object of this study was the commuting route of students in a primary school in Jinan, China. The selected school is a classic and traditional public primary school, and its commuting mode and surrounding traffic situation can therefore represent most primary schools in Jinan. The seasons selected in this study were winter and spring, as these seasons have relatively high concentrations of traffic-related pollutants. In addition, the rainy weather in summer and long summer holidays were not conducive to the measurement conducted in the present study. Due to the significance of the seasonal variations in pollutant concentrations due to climate change, climate should be taken into account when developing mitigation measures. It should be noted that nitrogen oxides are also traffic-related pollutants, but they were not analyzed in this paper, because this paper focused on the impact of particulate matter on students' respiratory system and calculated the respiratory deposition dose. The impact of nitrogen oxides on students' health mainly damaged students' cognitive and developmental nervous system (An et al. 2021; Sunyer et al. 2017).

\section{Particulate matter concentrations during the measurement}

While vehicle exhaust has a greater impact on the concentration of fine particulate matter (Nagpure et al. 2016; Yang et al. 2020; Yuan et al. 2013), the data collected in the present study indicate that the increase of coarse particulate matter was greater than that of fine particulate matter, which was not only caused by traffic exhaust. Due to the morning weather conditions in winter that the air relative humidity in the study area was high, the particulate matter could not be easily re-suspended under the influence of vehicles and human activities. As the temperature increased in the afternoon, the air relative humidity decreased, and particles were more likely to be re-suspended by the surrounding activity. As a result, the concentrations of particulate matter were higher in the afternoon than that in the morning in winter.

During the morning rush hour in spring, the airflow in the street canyon was relatively stable, and it was difficult for the particulate matter caused by traffic to dilute smoothly. The afternoon weather was often breezy, and the movement of the air carried out the pollutants that had accumulated in the street canyons. However, when the wind speed was too high, the amount of dust increased, resulting in the increase in the concentrations of particulate matter, as shown in A34-A36 and B32-B34 in Fig. 7. The limits of the specific wind speed require further exploration.

\section{Limitation of the test}

The increase in particulate matter concentrations caused by traffic includes two aspects, namely, direct emissions and dust resuspension (Harrison et al. 2012; Sinogaya and Manatad 2020). The resuspension of dust on roads makes it impossible to clearly distinguish the proportion of particulate matter concentration increases caused by traffic emissions, making it difficult to determine the impact of traffic exhaust emissions alone. From the perspective of students' health, regardless of the cause, elevated concentrations of particulate matter will threaten students' health. Dust sprinklers and decorative tree hedgerows are now widely used to alleviate dust exposure (Amini et al. 2016).

Previous studies have shown that the variation of the RDD between different commuting modes is often greater than the variation of the same commuting mode over the course of a day (Kumar et al. 2018). This study only considered the exposure risk of commuting on foot, and did not compare it with other commuting methods because most students in the study area commute on foot. In addition, this study focused on the necessity of choosing a low-risk route by comparing the exposure status and exposure risk between different routes under the same commuting mode.

\section{Limitation of background monitor station}

The data monitored by the background station reflect the concentrations of particulate matter at a certain height in a certain area, which can only reflect the air pollution situation over a wide range. It is evident from the large gap between the background concentration and the measured data, as well as the difference in the time distribution, that it is difficult for the background monitoring data to accurately represent the traffic pollution situation around the selected school during commuting, and it is not sufficiently objective to determine the actual traffic pollution exposure of students. Therefore, it is more advantageous to perfect traffic pollution monitoring systems, increase the number of monitoring points, and reduce the monitoring range.

\section{Mitigation measures}

The selection of route B was found to reduce students' particulate exposure by up to $22 \%$. Ignoring the effect of commuter routes can lead to a significant attenuation bias of $4 \%$ (95\% confidence interval: 4-5\%) (An et al. 2021; Ragettli et al. 2015). To reduce the exposure of students to traffic pollutants during the daily commute to and from school, schools and neighborhoods should encourage students to walk to school.

Trees and hedges can interrupt the transmission of trafficrelated pollutants. Vertical greening can effectively reduce 
$\mathrm{PM}_{2.5}$ concentration when road width is unchanged. Continuous planting of single rows of saplings leads to $17 \%$ reduction in $\mathrm{PM}_{2.5}$ levels (Ozdemir 2019). Meanwhile, urban greening can improve lung health among students in low-tomedium pollution areas (Zhou et al. 2021). Therefore, it is necessary to plant trees and hedges along the road.

It is also feasible to use pollutant filters to reduce the concentration of pollutants in the environment. Placing filters in areas with high pollutant concentrations (such as traffic hotspots) can reduce $\mathrm{PM}_{10}$ concentration by at least $4.1 \%$ (Bächler et al. 2021). In terms of pollution control, it is an important measure to eliminate vehicles with large emissions and encourage citizens to buy new energy vehicles. Parents could avoid idling when picking up and dropping off students, which can effectively reduce the concentration of particulate matter.

\section{Conclusion}

This study compared the exposure of primary school students to particulate matter on different commuting routes during commuting periods through the field measurements, and the following conclusions were drawn. In winter and spring, the concentrations of $\mathrm{PM}_{2.5}$ and $\mathrm{PM}_{10}$ on route $\mathrm{A}$ (high-traffic route that is near the main road) were greater than those on route B (low-traffic route that is off the main road), with respective averages of 1.2- and 1.1-fold increases. The average annual amount of $\mathrm{PM}_{2.5}$ inhalation on route B over 3 years was found to be $16.3 \%$ lower than that on route $\mathrm{A}$. Therefore, the selection of route $\mathrm{B}$ will significantly reduce the amount of $\mathrm{PM}_{2.5}$ inhaled by commuting students.

Traffic activity exacerbates pollution with particulate concentrations. When the background particulate concentration is high, the wind velocity has little effect on the alleviation of particulate concentration in the environment. When the background particulate concentration is low in spring, the wind velocity can reduce the particulate concentration on the commuting route to some extent. To reduce exposure to traffic-related pollution, there will often be a lower-dose route. According to the characteristics of route $\mathrm{B}$, it is necessary to choose a commuter route that is far away from the main road and to avoid traffic intersections and traffic lights; thus, roads within communities are better choices for student commuters.

Nomenclature BC: Black carbon; RDD: Respiratory deposition dose $(\mu \mathrm{g} / \mathrm{min})$; TRDD: Total respiratory deposition dose $(\mu \mathrm{g} / \mathrm{min})$; UFPs: Ultrafine particles; PM: Particulate matter; PMC: Particulate matter concentration $\left(\mu \mathrm{g} / \mathrm{m}^{3}\right)$; PNC: Particulate matter number; ICRP: International Commission on Radiological Protection; $V_{T}$ : Tidal volume $\left(\mathrm{cm}^{3}\right) ; B F$ : Breathing frequency (breaths/second);
$D F$ : Deposition fraction; $I F$ : Inhalable fraction; $d_{p}$ : Average particle diameter; $T_{e}$ : Annual commuting exposure time

Supplementary Information The online version contains supplementary material available at https://doi.org/10.1007/s11356-021-18362-w.

Acknowledgements The authors would like to thank Xicheng Wang, Junhui Li, Zhenlong Fan, Yiming Qiao, and Jie Zhou for collecting data. The authors also would like to thank the Plan of Introduction and Cultivation for Young Innovative Talents in Colleges and Universities of Shandong Province.

Author contribution Farun An collected the data, analyzed the data, and wrote the original draft. Jiying Liu provided the research concepts and methodology and reviewed and edited the manuscript. Wanpeng $\mathrm{Lu}$ and Daranee Jareemit reviewed and edited the article. All authors read and approved the final manuscript.

Funding This work was funded by the Support Plan for Outstanding Youth Innovation Team in Colleges and Universities of Shandong Province (2019KJG005), Natural Science Foundation of Shandong Province (ZR2020ME211, ZR2021ME199) and Thammasat University Funding (JRA-CO-2563-13105-TH).

Data availability The datasets used and/or analyzed during the current study are available from the corresponding author on reasonable request.

\section{Declarations}

Ethics approval and consent to participate The study was conducted according to the guidelines of the Declaration of Helsinki and approved by the Ethics Committee (represented by Science and Technology Department) of Shandong Jianzhu University. Verbal consents were obtained from participants.

Consent for publication The authors are giving their consent for this study to be published in the journal of Environment Science Pollution Research.

Competing interests The authors declare no competing interests.

\section{References}

Adeniran JA, Yusuf RO, Olajire AA (2017) Exposure to coarse and fine particulate matter at and around major intra-urban traffic intersections of Ilorin metropolis, Nigeria. Atmos Environ 166:383-392. https://doi.org/10.1016/j.atmosenv.2017.07.041

Ahmed S, Adnan M, Janssens D, Wets G (2020) A route to school informational intervention for air pollution exposure reduction. Sustain Cities Soc 53:101965. https://doi.org/10.1016/j.scs.2019. 101965

An F, Liu J, Lu W, Jareemit D (2021) A review of the effect of trafficrelated air pollution around schools on student health and its mitigation. J Transp Health 23:101249. https://doi.org/10.1016/j.jth. 2021.101249

ASHRAE (2013). Method of Testing for Room Air Diffusion vol ANSI/ASHRAE 113-2013. Atlanta

Azarmi F, Kumar P (2016) Ambient exposure to coarse and fine particle emissions from building demolition. Atmos Environ 137:6279. https://doi.org/10.1016/j.atmosenv.2016.04.029 
Bächler P, Müller TK, Warth T, Yildiz T, Dittler A (2021) Impact of ambient air filters on PM concentration levels at an urban traffic hotspot (Stuttgart, Am Neckartor). Atmos Pollut Res 12:101059. https://doi.org/10.1016/j.apr.2021.101059

Bai L, Su X, Zhao D et al (2018) Exposure to traffic-related air pollution and acute bronchitis in children: season and age as modifiers. J Epidemiol Community Health 72:426-433. https://doi.org/10. 1136/jech-2017-209948

Basagana X, Esnaola M, Rivas 1. et al (2016) Neurodevelopmental Deceleration by Urban Fine Particles from Different Emission Sources: A Longitudinal Observational Study. Environ Health Perspect 124:1630-1636. https://doi.org/10.1289/EHP209

Bhaskaran K, Hajat S, Armstrong B, Haines A, Herrett E, Wilkinson P, Smeeth L (2011) The effects of hourly differences in air pollution on the risk of myocardial infarction: case crossover analysis of the MINAP database. BMJ 343:d5531. https://doi.org/10.1136/ bmj.d5531

Brown L, Barnes J, Hayes E (2021) Traffic-related air pollution reduction at UK schools during the Covid-19 lockdown. Sci Total Environ 780:146651. https://doi.org/10.1016/j.scitotenv.2021.146651

Brugha R, Grigg J (2014) Urban air pollution and respiratory infections. Paediatr Respir Rev 15:194-199. https://doi.org/10.1016/j. prrv.2014.03.001

Buonanno G, Fuoco FC, Morawska L, Stabile L (2013) Airborne particle concentrations at schools measured at different spatial scales. Atmos Environ 67:38-45. https://doi.org/10.1016/j.atmos env.2012.10.048

Chen Z, Cui L, Cui X et al (2019) The association between high ambient air pollution exposure and respiratory health of young children: a cross sectional study in Jinan, China. Sci Total Environ 656:740-749. https://doi.org/10.1016/j.scitotenv.2018.11.368

Cole-Hunter T, Morawska L, Stewart I, Jayaratne R, Solomon C (2012) Inhaled particle counts on bicycle commute routes of low and high proximity to motorised traffic. Atmos Environ 61:197-203. https://doi.org/10.1016/j.atmosenv.2012.06.041

Cui L, Zhou J, Peng X, Ruan S, Zhang Y (2020) Analyses of air pollution control measures and co-benefits in the heavily air-polluted Jinan city of China, 2013-2017. Sci Rep 10:5423. https://doi.org/ $10.1038 / \mathrm{s} 41598-020-62475-0$

Dillman K, Czepkiewicz M, Heinonen J, Fazeli R, Árnadóttir Á, Davíðsdóttir B, Shafiei E (2021) Decarbonization scenarios for Reykjavik's passenger transport: the combined effects of behavioural changes and technological developments. Sustain Cities Soc 65:102614. https://doi.org/10.1016/j.scs.2020.102614

Dirks K, Wang J, Khan A, Rushton C (2016) Air pollution in relation to the commute to school: a Bradford case study. Int J Environ Res Public Health 13:1064. https://doi.org/10.3390/ijerph13111064

Dons E, Int PL, Van Poppel M, Theunis J, Willems H, Torfs R, Wets G (2011) Impact of time-activity patterns on personal exposure to black carbon. Atmos Environ 45:3594-3602. https://doi.org/10. 1016/j.atmosenv.2011.03.064

Elford S, Adams MD (2019) Exposure to ultrafine particulate air pollution in the school commute: examining low-dose route optimization with terrain-enforced dosage modelling. Environ Res 178:108674. https://doi.org/10.1016/j.envres.2019.108674

Garcia-Algar O, Canchucaja L, d'Orazzio V, Manich A, Joya X, Vall O (2014) Different exposure of infants and adults to ultrafine particles in the urban area of Barcelona. Environ Monit Assess 187:4196. https://doi.org/10.1007/s10661-014-4196-5

Goel A, Kumar P (2015) Zone of influence for particle number concentrations at signalised traffic intersections. Atmos Environ 123:2538. https://doi.org/10.1016/j.atmosenv.2015.10.054

Goyal R, Kumar P (2013) Indoor-outdoor concentrations of particulate matter in nine microenvironments of a mix-use commercial building in megacity Delhi. Air Qual Atmos Health 6:747-757. https:// doi.org/10.1007/s11869-013-0212-0
Harrison RM, Jones AM, Gietl J, Yin J, Green DC (2012) Estimation of the contributions of brake dust, tire wear, and resuspension to nonexhaust traffic particles derived from atmospheric measurements. Environ Sci Technol 46:6523-6529. https://doi.org/10. 1021/es300894r

Harrison RM, Vu TV, Jafar H, Shi Z (2021) More mileage in reducing urban air pollution from road traffic. Environ Int 149:106329. https://doi.org/10.1016/j.envint.2020.106329

He C, Qiu K, Pott R (2020) Reduction of urban traffic-related particulate matter-leaf trait matters. Environ Sci Pollut Res 27:5825-5844. https://doi.org/10.1007/s11356-019-07160-0

Hinds W (1999) Aerosol technology: properties behaviour and measurement of airborne particles. Wiley, New York. https://doi.org/ 10.1016/S0021-8502(99)00571-6

ISO (1995) Guide to the expression of uncertainty in measurements. United States. https://doi.org/10.2172/1402579

Karageorgou K, Manoli E, Kouras A, Samara C (2021) Commuter exposure to particle-bound polycyclic aromatic hydrocarbons in Thessaloniki, Greece. Environ Sci Pollut Res 28:59119-59130. https://doi.org/10.1007/s11356-020-09475-9

Kim HH, Lee CS, Jeon JM et al (2013) Analysis of the association between air pollution and allergic diseases exposure from nearby sources of ambient air pollution within elementary school zones in four Korean cities. Environ Sci Pollut Res 20:4831-4846. https://doi.org/10.1007/s11356-012-1358-2

Kumar P, Goel A (2016) Concentration dynamics of coarse and fine particulate matter at and around signalised traffic intersections. Environ Sci Process Impacts 18:1220-1235. https://doi.org/10. 1039/C6EM00215C

Kumar P, Omidvarborna H, Barwise Y, Tiwari A (2020a) Mitigating exposure to traffic pollution in and around schools guidance for children. Schools and Local Communities 24. https://doi.org/ 10.5281/zenodo.3754131

Kumar P, Omidvarborna H, Pilla F, Lewin N (2020b) A primary school driven initiative to influence commuting style for dropping-off and picking-up of pupils. Sci Total Environ 727:138360. https://doi.org/10.1016/j.scitotenv.2020.138360

Kumar P, Rivas I, Sachdeva L (2017) Exposure of in-pram babies to airborne particles during morning drop-in and afternoon pick-up of school children. Environ Pollut 224:407-420. https://doi.org/ 10.1016/j.envpol.2017.02.021

Kumar P, Rivas I, Singh AP, Ganesh VJ, Ananya M, Frey HC (2018) Dynamics of coarse and fine particle exposure in transport microenvironments. npj Clim Atmos Sci 1:11. https://doi.org/ 10.1038/s41612-018-0023-y

Li B, Lei X-N, Xiu G-L, Gao C-Y, Gao S, Qian N-S (2015) Personal exposure to black carbon during commuting in peak and offpeak hours in Shanghai. Sci Total Environ 524-525:237-245. https://doi.org/10.1016/j.scitotenv.2015.03.088

Li HC, Chiueh PT, Liu SP, Huang YY (2017) Assessment of different route choice on commuters' exposure to air pollution in Taipei, Taiwan. Environ Sci Pollut Res Int 24:3163-3171. https:// doi.org/10.1007/s11356-016-8000-7

Li X, Song H, Zhai S, Lu S, Kong Y, Xia H, Zhao H (2019) Particulate matter pollution in Chinese cities: areal-temporal variations and their relationships with meteorological conditions (2015-2017). Environ Pollut 246:11-18. https://doi.org/10. 1016/j.envpol.2018.11.103

Madureira J, Slezakova K, Silva AI et al (2020) Assessment of indoor air exposure at residential homes: inhalation dose and lung deposition of PM10, PM2.5 and ultrafine particles among newborn children and their mothers. Sci Total Environ 717:137293. https://doi.org/10.1016/j.scitotenv.2020.137293

Mathioulakis E, Voropoulos K, Belessiotis V (1999) Assessment of uncertainty in solar collector modeling and testing. Sol Energy 66:337-347. https://doi.org/10.1016/S0038-092X(99)00034-1 
McConnell R, Islam T, Shankardass K et al (2010) Childhood incident asthma and traffic-related air pollution at home and school. Environ Health Perspect 118:1021-1026. https://doi.org/10. 1289/ehp.0901232

Mei D, Wen M, Xu X, Zhu Y, Xing F (2018) The influence of wind speed on airflow and fine particle transport within different building layouts of an industrial city. J Air Waste Manag Assoc 68:1038-1050. https://doi.org/10.1080/10962247.2018.1465487

Miao Q, Bouchard M, Chen D, Rosenberg MW, Aronson KJ (2015) Commuting behaviors and exposure to air pollution in Montreal, Canada. Sci Total Environ 508:193-198. https://doi.org/ 10.1016/j.scitotenv.2014.11.078

Mohai P, Kweon BS, Lee S, Ard K (2011) Air pollution around schools is linked to poorer student health and academic performance. Health Aff (millwood) 30:852-862. https://doi.org/10. 1377/hlthaff.2011.0077

Mölter A, Lindley S (2015) Influence of walking route choice on primary school children's exposure to air pollution-a proof of concept study using simulation. Sci Total Environ 530-531:257262. https://doi.org/10.1016/j.scitotenv.2015.05.118

Nagpure AS, Gurjar BR, Kumar V, Kumar P (2016) Estimation of exhaust and non-exhaust gaseous, particulate matter and air toxics emissions from on-road vehicles in Delhi. Atmos Environ 127:118-124. https://doi.org/10.1016/j.atmosenv.2015.12.026

Onyango S, Parks B, Anguma S, Meng Q (2019) Spatio-temporal variation in the concentration of inhalable particulate matter (PM(10)) in Uganda. Int J Environ Res Public Health 16:1752. https://doi.org/10.3390/ijerph16101752

Ozdemir H (2019) Mitigation impact of roadside trees on fine particle pollution. Sci Total Environ 659:1176-1185. https://doi. org/10.1016/j.scitotenv.2018.12.262

Pang Y, Liu S, Yan L et al (2021) Associations of long-term exposure to traffic-related air pollution with risk of valvular heart disease based on a cross-sectional study. Ecotoxicol Environ Saf 209:111753. https://doi.org/10.1016/j.ecoenv.2020.111753

Pastor M, Sadd JL, Morello-Frosch R (2004) Reading, writing, and toxics: children's health, academic performance, and environmental justice in Los Angeles. Environ Plann C Gov Policy 22:271-290. https://doi.org/10.1068/c009r

Patel V, Kantipudi N, Jones G, Upton A, Kamath MV (2016) Air pollution and cardiovascular disease: a review. Crit Rev Biomed Eng 44:327-346. https://doi.org/10.1615/CritRevBiomedEng. 2017019768

Patterson R, Zhang Q, Zheng M, Zhu Y (2014) Particle deposition in respiratory tracts of school-aged children. Aerosol Air Qual Res 14:64-73. https://doi.org/10.4209/aaqr.2013.04.0113

Peng J, Zhang L, Meng Q et al (2019) Adverse impact of ambient PM2.5 on expression and trafficking of surfactant protein A through reactive oxygen species damage to lamellar bodies. Toxicol Lett 315:47-54. https://doi.org/10.1016/j.toxlet.2019. 08.015

Pipal AS, Kulshrestha A, Taneja A (2011) Characterization and morphological analysis of airborne PM2.5 and PM10 in Agra located in north central India. Atmos Environ 45:3621-3630. https://doi.org/10.1016/j.atmosenv.2011.03.062

Qiu Z, Song J, Xu X et al (2017) Commuter exposure to particulate matter for different transportation modes in Xi'an, China. Atmos Pollut Res 8:940-948. https://doi.org/10.1016/j.apr. 2017.03.005

Ragettli MS, Phuleria HC, Tsai M-Y et al (2015) The relevance of commuter and work/school exposure in an epidemiological study on traffic-related air pollution. J Exposure Sci Environ Epidemiol 25:474-481. https://doi.org/10.1038/jes.2014.83

Ragettli MS, Tsai MY, Braun-Fahrländer C et al (2014) Simulation of population-based commuter exposure to $\mathrm{NO}_{2}$ using different air pollution models. Int J Environ Res Public Health 11:5049_ 5068. https://doi.org/10.3390/ijerph110505049

Rivas I, Donaire-Gonzalez D, Bouso L et al (2016) Spatiotemporally resolved black carbon concentration, schoolchildren's exposure and dose in Barcelona. Indoor Air 26:391-402. https://doi.org/ 10.1111/ina.12214

Rosofsky A, Lucier CA, London B, Scharber H, Borges-Mendez R, Shandra J (2014) Environmental ascription in Worcester County, MA: toxic pollution and education outcomes. Local Environ 19:283-299. https://doi.org/10.1080/13549839.2013. 788485

Shapiro SS, Francia RS (1972) An approximate analysis of variance test for normality. J Am Stat Assoc 67:215-216. https://doi.org/ 10.1080/01621459.1972.10481232

Sinogaya J, Manatad MC (2020) Measurement and modeling of particulate matter (PM10) concentration from onroad vehicles in Metro Cebu, Philippines. International Journal of Innovation Engineering and Science Research 4:19-30. https://ijiesr.com/ liebrary/e28/922427243.pdf. Accessed 26 Dec 2021

Song J, Qiu Z, Ren G, Li X (2020) Prediction of pedestrian exposure to traffic particulate matters (PMs) at urban signalized intersection. Sustain Cities Soc 60:102153. https://doi.org/10.1016/j. scs.2020.102153

Srimuruganandam B, Shiva Nagendra SM (2010) Analysis and interpretation of particulate matter - PM10, PM2.5 and PM1 emissions from the heterogeneous traffic near an urban roadway. Atmos Pollut Res 1:184-194. https://doi.org/10.5094/APR. 2010.024

Sunyer J, Suades-González E, García-Esteban R et al (2017) Trafficrelated air pollution and attention in primary school children: short-term association. Epidemiology 28:181-189. https://doi. org/10.1097/ede.0000000000000603

Tang J, McNabola A, Misstear B (2020) The potential impacts of different traffic management strategies on air pollution and public health for a more sustainable city: a modelling case study from Dublin, Ireland. Sustain Cities Soc 60:102229. https://doi.org/ 10.1016/j.scs.2020.102229

Tischer V, Fountas G, Polette M, Rye T (2019) Environmental and economic assessment of traffic-related air pollution using aggregate spatial information: a case study of Balneário Camboriú, Brazil. J Transp Health 14:100592. https://doi.org/10.1016/j. jth.2019.100592

van Berlo D, Albrecht C, Knaapen AM et al (2010) Comparative evaluation of the effects of short-term inhalation exposure to diesel engine exhaust on rat lung and brain. Arch Toxicol 84:553-562. https://doi.org/10.1007/s00204-010-0551-7

Wadlow I, Paton-Walsh C, Forehead H et al (2019) Understanding spatial variability of air quality in Sydney: part 2-a roadside case study. Atmosphere 10:217. https://doi.org/10.3390/atmos 10040217

Walker D, Utell M, FramptonMillerJones MGD (2019) High-resolution metabolomics in human clinical studies of traffic-related pollutants. Environ Epidemiol 3:419-420. https://doi.org/10. 1097/01.EE9.0000610700.16724.c5

Wang J (2013) Air quality online monitoring and analysis platform. https://www.aqistudy.cn/. Accessed 26 Dec 2021

Xiao S, Guan X, Gu C, Liu L, Yang Y, Wang L (2019) Temporal distribution characteristics of air quality at a national monitoring point in haikou from 2016 to 2017. Nat Sci J Hainan Univ 37:247-253. https://doi.org/10.15886/j.cnki.hdxbzkb.2019.0035 ((in Chinese))

Yang G, Zhang Y, Li X (2020) Impact of gasoline upgrade policy on particulate matter pollution in China. J Cleaner Prod 262:121336. https://doi.org/10.1016/j.jclepro.2020.121336

Yuan B, Hu WW, Shao M et al (2013) VOC emissions, evolutions and contributions to SOA formation at a receptor site in eastern 
China. Atmos Chem Phys 13:8815-8832. https://doi.org/10. 5194/acp-13-8815-2013

Zhao J, Ji Y, Li Y, Zhang L, Wang S (2019) Distribution characteristics of traffic volume for typical roads in Tianjin City. Res Environ Sci 32:399-405. https://doi.org/10.13198/j.issn.10016929.2018.06.22 ((in Chinese))

Zheng T, Wang H-W, Li X-B, Peng Z-R, He H-D (2021) Impacts of traffic on roadside particle variations in varied temporal scales. Atmos Environ 253:118354. https://doi.org/10.1016/j.atmosenv. 2021.118354

Zhou X, Strezov V, Jiang Y, Kan T, Evans T (2022) Temporal and spatial variations of air pollution across China from 2015 to 2018. J Environ Sci 112:161-169. https://doi.org/10.1016/j.jes.2021.04. 025
Zhou Y, Bui DS, Perret JL et al (2021) Greenness may improve lung health in low-moderate but not high air pollution areas: Seven Northeastern Cities' study. Thorax. https://doi.org/10.1136/thora xjnl-2020-214767

Zhu S, Lian X, Wei L et al (2018) PM2.5 forecasting using SVR with PSOGSA algorithm based on CEEMD, GRNN and GCA considering meteorological factors. Atmos Environ 183:20-32. https:// doi.org/10.1016/j.atmosenv.2018.04.004

Publisher's note Springer Nature remains neutral with regard to jurisdictional claims in published maps and institutional affiliations. 